九州大学学術情報リポジトリ

Kyushu University Institutional Repository

\title{
Sedimentology of the Cretaceous Mikasa
} Formation

Okada, Hakuyu

Faculty of Science, Kyushu University

https://doi.org/10.5109/1543625

出版情報：九州大學理學部紀要：Series D, Geology. 16（1)，pp.81-111，1965-03-25. Faculty of Science, Kyushu University バージョン :

権利関係 : 


\title{
Sedimentology of the Cretaceous Mikasa Formation
}

\author{
By
}

\section{Hakuyu OKADA}

\begin{abstract}
The Cretaceous Mikasa Formation is typically exposed in the Ikushumbets area, central Hokkaido, which is one of the type areas of the Cretaceous System in Japan. This paper contains the results of the petrological study of the sandstone of the Mikasa Formation.

Two types of sandstone, graywackes and subgraywackes, are developed in harmony with a number of geological facts. On each rock type textural and mineralogical features have been examined, and its depositional conditions are discussed. Further comments are extended to some characteristics of heavy minerals. Comparison of the Mikasa Formation with that of other related stratigraphic units are also described.

Detritus of the sediments came mainly from western uplands, where source rocks were chiefly composed of older sedimentaries and subordinately of acid to ultrabasic igneous rocks.
\end{abstract}

\section{Contents}

I. Introduction $\ldots \ldots \ldots \ldots \ldots \ldots \ldots \ldots \ldots \ldots \ldots \ldots \ldots \ldots \ldots \ldots \ldots \ldots \ldots \ldots$

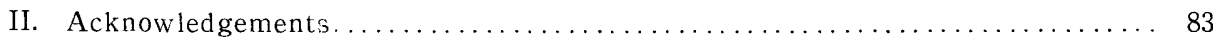

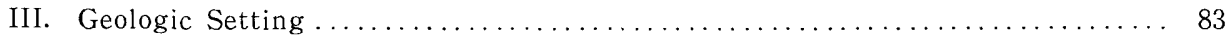

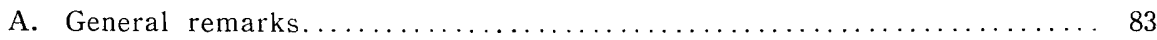

B. Notes on stratigraphy of the Mikasa Formation $\ldots \ldots \ldots \ldots \ldots \ldots \ldots \ldots 86$

IV. Petrology $\ldots \ldots \ldots \ldots \ldots \ldots \ldots \ldots \ldots \ldots \ldots \ldots \ldots \ldots \ldots \ldots \ldots \ldots \ldots \ldots \ldots \ldots \ldots$

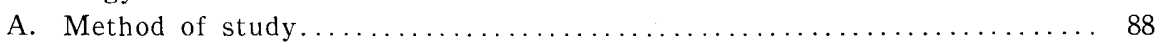

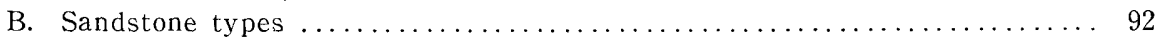

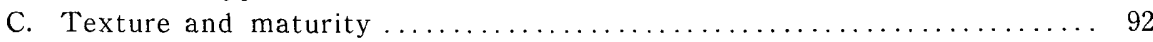

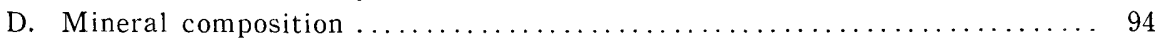

E. A few comments on heavy mineral suites .................... 100

F. A note on the sandstones of the Cretaceous section along the Ikushumbets

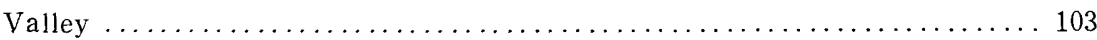

G. A note on the Lower Tertiary sandstones $\ldots \ldots \ldots \ldots \ldots \ldots \ldots \ldots \ldots \ldots$

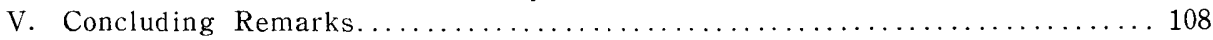

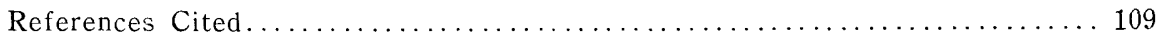

\section{Introduction}

The Ikushumbets area in Hokkaido, which occupies the middle part of the western periphery of the Cretaceous outcrops in and along the backbone of Hokkaido (Fig. 1), is one of the type areas of the Cretaceous System in Japan. Since YABE's

* Manuscript received September 30, 1964. 


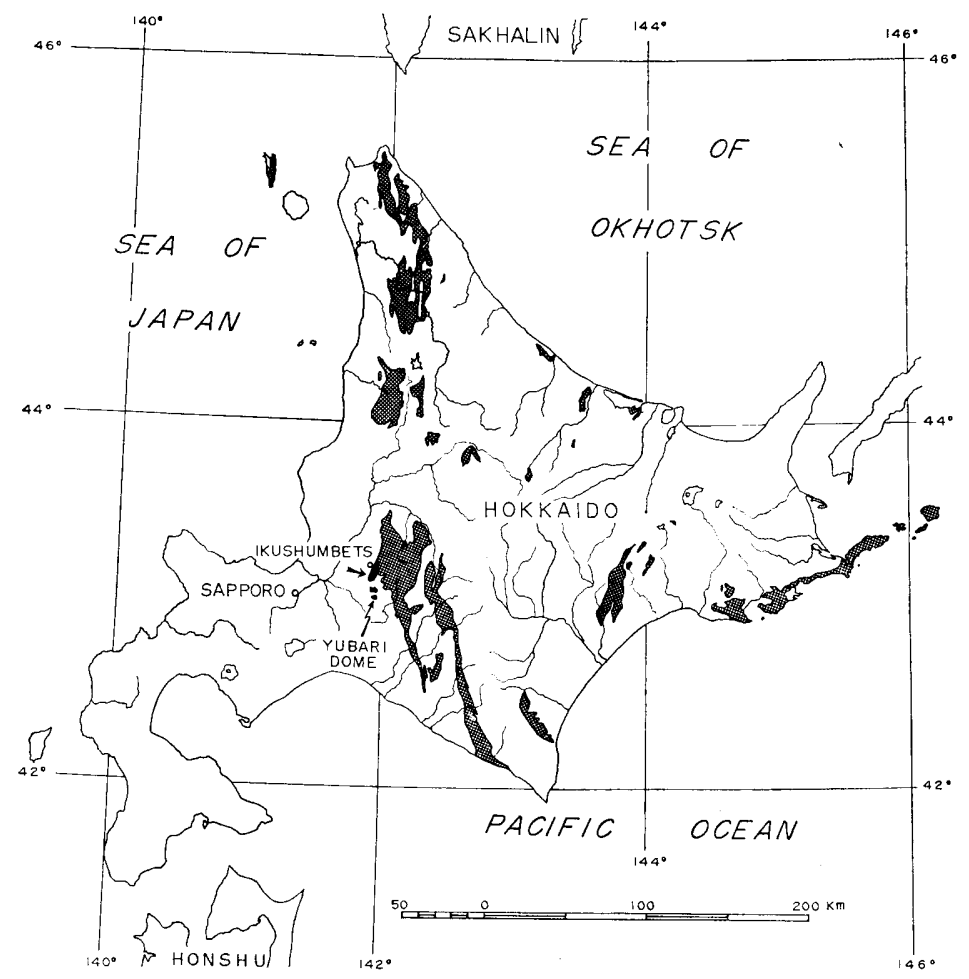

Fig. 1. Index map of Hokkaido showing distribution of the Cretaceous deposits. The investiated area is indicated by a black spot with an arrow.

pioneer researches (YABE, 1903, 1909, 1926a and b, 1927), therefore, many geological and palaeontological studies have been undertaken and are being carried on. Especially, an up-to-date stratigraphic scheme has been established by MATsumoto (1959, etc.; see Fig. 5) for the classical section along the Ikushumbets Valley.

Of the marine Cretaceous in this area, I have undertaken a sedimentological study, especially petrological study of the Mikasa Formation (Cenomanian to Turonian) of the Middle Yezo Group (Albian to Turonian), succeeding to a pioneer approach to this study by FuJII (1958). The Mikasa Formation, which has been accustomed to be called the "Trigonia Sandstone" since YABE (1903) denominated so, is not only important for the subject of palaeontologic studies but also interesting for the sedimentological viewpoint. It is characterized for the most part by coarse clastics such as sandstones and conglomerates.

Unlike the flat-lying or gently inclined beds on the well-known shelf areas in Europe and North America, the Cretaceous strata of Hokkaido are intensely folded. Therefore there is some difficulty in the study of the lithological change. The Mikasa Formation displays an anticlinal structure of NNE-SSW trend (Fig. 2). Fortunately there are a number of streams cutting across the formation which generally exhibit good exposures. This gives us the situation as if a number of borings were drilled at certain intervals. 
The purpose of this paper is to describe the petrologic characters of the Mikasa sandstone, to make clear the geological and sedimentological environments at the time of deposition and also to elucidate palaeogeographic conditions. In connection with this, comparison is attempted between the sandstone of the Mikasa Formation and that of the overlying and underlying stratigraphic units as well as the contemporary deposits in the Yubari dome (Fig. 1).

\section{Acknowledgements}

It is a great pleasure to record here a debt of gratitude to Professor Tatsuro MAтsumoto of Kyushu University, who has suggested this study, freely given me necessary information of stratigraphy, provided me with various fascilities for study and read the manuscript with invaluable criticism.

Further, I wish to acknowledge several companies and persons: My gratitude is due to the Japan Petroleum Exploration Co., Ltd., the Sumitomo Coal Mining Co., Ltd., the Hokkaido Colliery and Steamship Co., Ltd. and the Higashihoronai Coal Mining Co., Ltd. for their help in accomodation and transportation in my field works. I am also greatly indebted to Drs. Koji Kinoshita and Yuzuru Agatsuma of the Japan Petroleum Exploration Co., Ltd., Drs. Kametoshi Kanmera, Jyonosuke OHARA and Akira Momor and Mr. Sadanori Mryachi of Kyushu University, Dr. Hisao SHIMOGAWARA of the Hokkaido Colliery and Steamship Co., Ltd. and Mr. Ichiro HAYASHI of the Sumitomo Coal Mining Co., Ltd., for their help in many ways. Furthermore, I wish to express my gratitude to Messrs. Tatsuo Muramoto and Kikuo MURAmoto for their kind assistance in collecting some sandstone samples. Miss Misako KIDO has kindly assisted me in draughting and my wife has helped me in typing the manuscript.

This study was partly carried out in aid of a grant through Professor. Tatsuro Matsumoto from the Ministry of Education.

\section{Geologic Setting}

\section{A. General remarks}

The Cretaceous System in the Ikushumbets area, the type section of which is along the Ikushumbets Valley, makes up an anticlinal structure of north-northeast trend that stretches over $40 \mathrm{~km}$ from Utashinai City to Miruto, Kurisawa-machi, Sorachi-gun, and constitutes a basement of the coal-bearing Palaeogene of the Ishikari coal field. The northern half of this structure is named the Sorachi anticline and the southern half the Ikushumbets anticline (Fig. 2). This study is focussed on the Mikasa Formation in the Ikushumbets anticlinal area.

The Cretaceous sequence in the Ikushumbets anticlinal area is subdivisible into the Middle Yezo Group and the Upper Yezo Group. The Middle Yezo Group, ranging from Albian to Turonian in age, occupies the axial part of the anticline in distribution. Although the basal part is unknown in this area, the Group consists generally of muddy facies in the lower part and sandy facies in the upper part. The latter is 
denominated the Mikasa Formation (or the Mikasa Sandstone Formation) (MATsumoto, 1951), that was formerly called the Trigonia Sandstone (YABE, 1903, 1909, 1926a and b, 1927). This formation grades into the overlying Upper Yezo Group.

The Upper Yezo Group, which is distributed mainly on the eastern wing of the anticline, consists in general of mudstones frequently with fossiliferous nodules, being accompanied with a few glauconitic sandstone beds and layers of tuff. This Group ranges from Upper Turonian to Santonian in age.

As characteristic features of major geological structures, the western flank of the anticline is very steeply inclined: in many places vertical or even overturned, while the eastern one shows as moderate inclination as 30 to 40 degrees. The axial

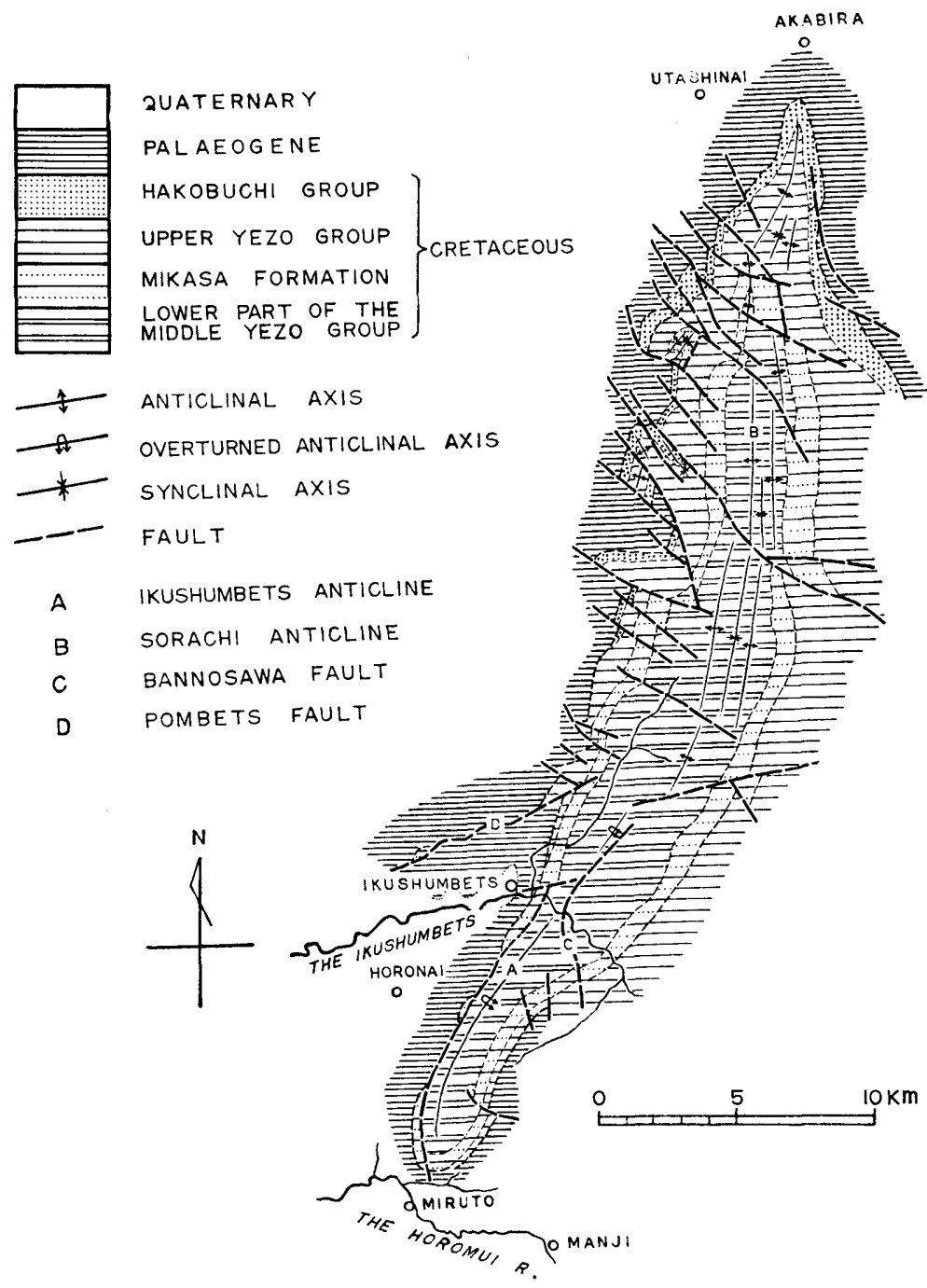

Fig. 2. Compiled geologic map of the outcrop areas of the Mikasa Formation in the Ishikari coal field. 


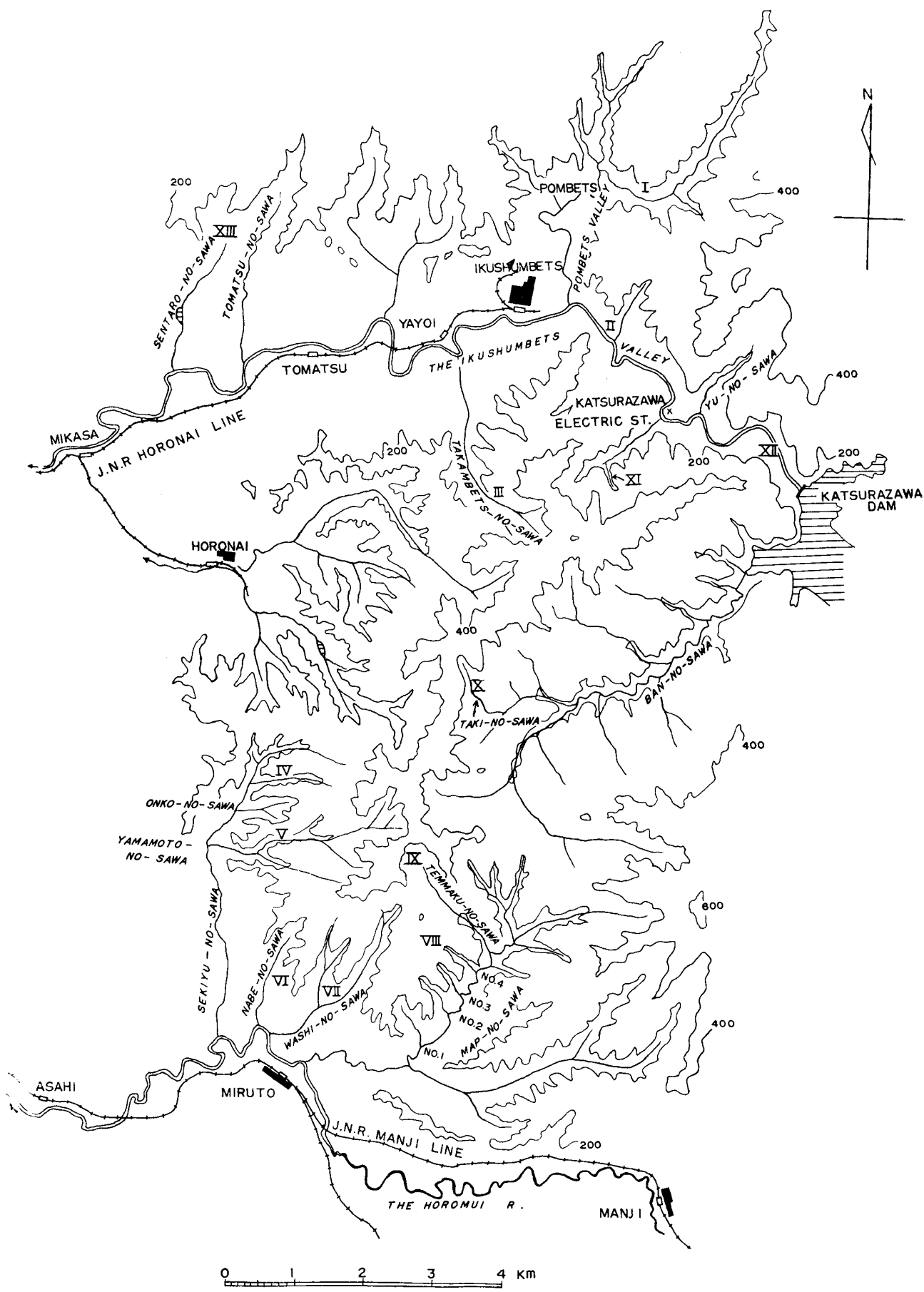

Fig. 3. Drainage system in the Ikushumbets area. 
plane is overturned northwest by 40 degrees at one place (e.g. observed at loc. 206 it the Yamamoto-no-sawa [V]. see Figs. 3 and 4). Transverse faults of a northwest trend are prominent over the whole anticlinal area besides a thrust on a considerable

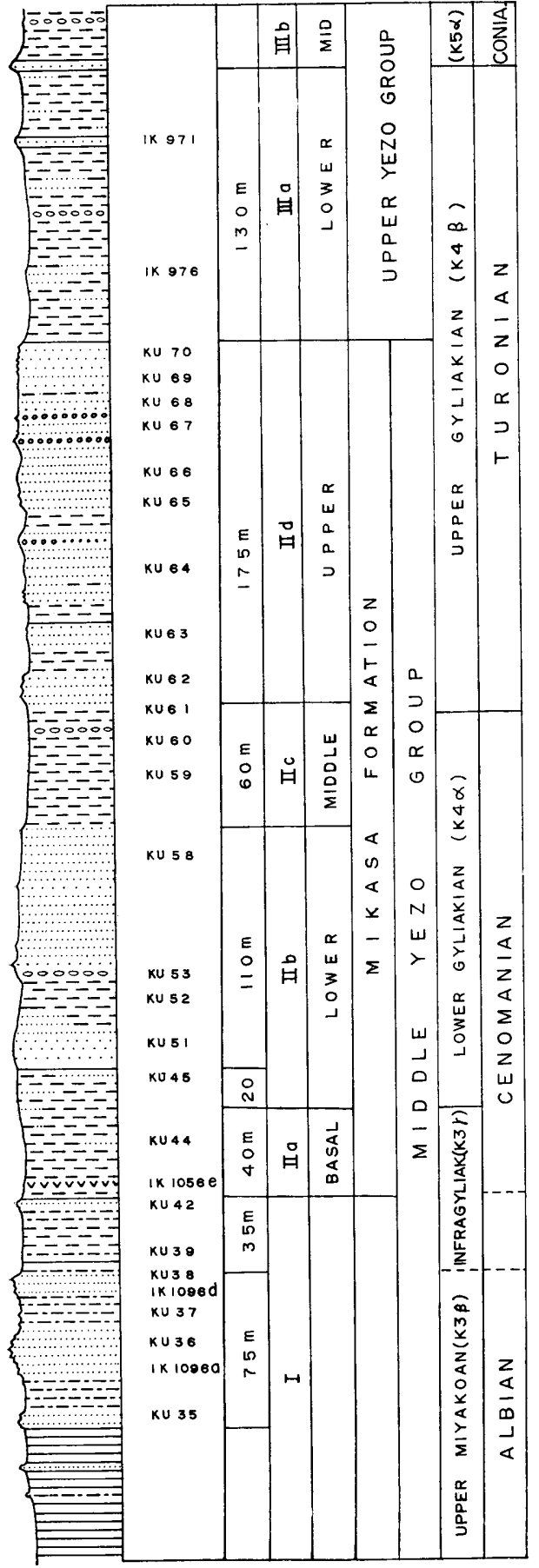
scale across the Ikushumbets Valley [Bannosawa thrust (OTATUME, 1940-'41) (c) in Fig. 2].

The outline of stratigraphy and palaeontology of certain groups of mollusca of the Cretaceous in this area have been published by Prof. Tatsuro Matsumoto sometimes with his coworkers.

\section{B. Notes on the stratigraphy of the Mikasa Formation}

(1) Type area. Matsumoto (1951) introduced the name of the Mikasa Formation for a unit of the sandy facies of the Gyliakian (approximately Cenomanian to Turonian) sequence, which was called the Trigonia Sandstone by YABE (1903, 1926a and b, 1927). Its type is in the Ikushumbets Valley area near the Ishikari coal field (Figs. 3, 4 and 5). It is exposed in other areas of the Ishikari coalfield, such as Bibai, Miruto, Yubari, etc. The outcropping area represents the western part of the Cretaceous terrain in the meridional belt of Hokkaido (see Matsumoto, 1943, P. 176).

(2) Subdivision. According to Matsumoto (1954, 1959) and Matsumoto et al. (1960), the Mikasa Formation in the section along the Ikushumbets Valley on the eastern wing of the anticline is subdivided into the following four members; Basal [IIa], Lower [IIb], Middle [IIc] and Upper [IId] (Fig. 5).

(a) Basal Member [IIa], $40 \mathrm{~m}$ thick, is mainly composed of dark greenish grey and

Fig. 5. Standard stratigraphic section along the Ikushumbets Valley (on the eastern wing) prepared by Matsumoto (1959), and positions of the rock samples.

Explanation of lithology in the columnar section is shown in Fig. 6. 


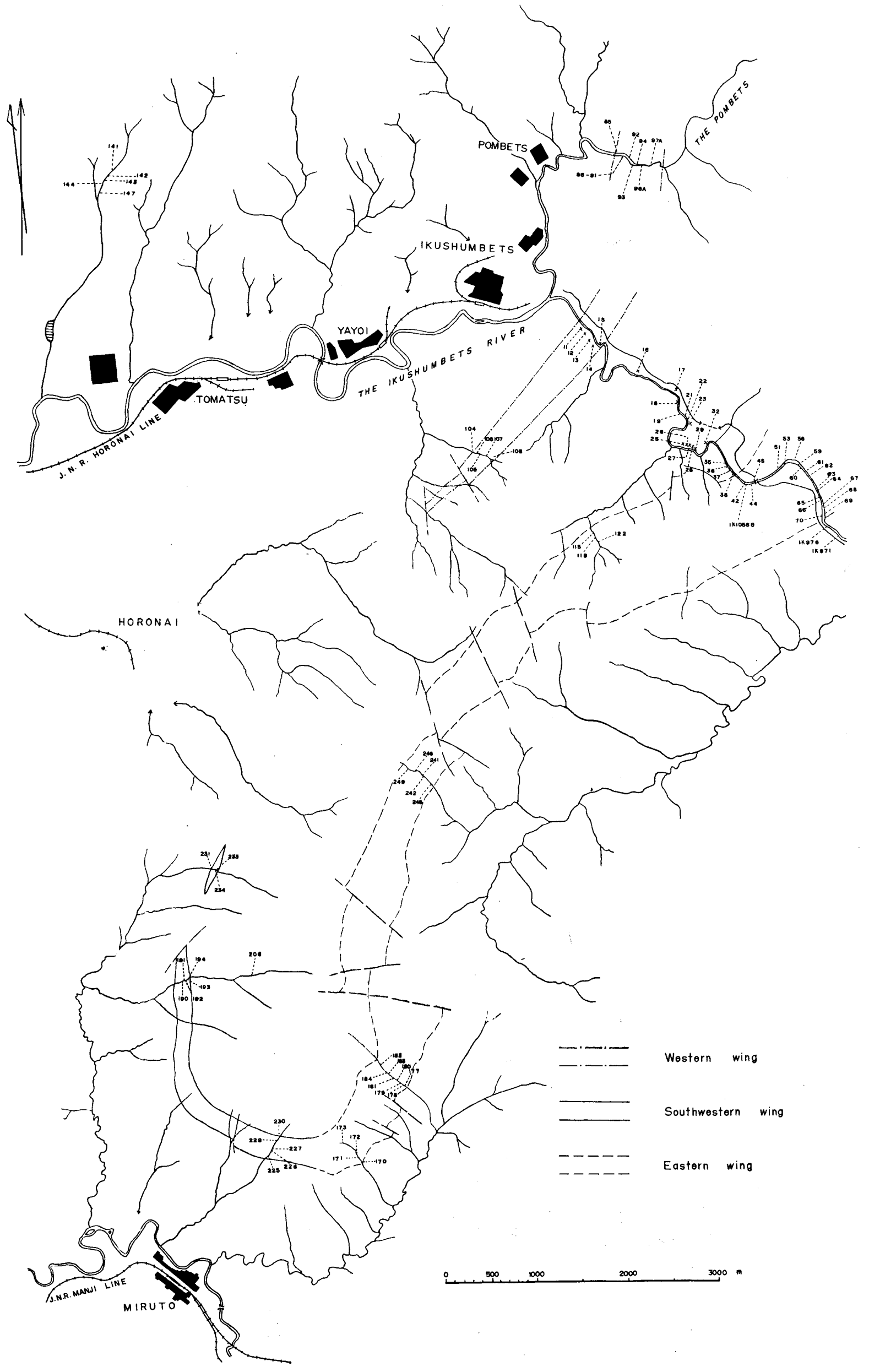

Fig. 4. Map showing distribution of the Mikasa Formation in the Ikushumbets anticlinal area and the localities where the examined specimens were collected. 
massive sandy-siltstone intercalated rarely with thin beds of very fine-grained sandstone. The siltstone is rich in calcareous nodules of various sizes which commonly contain Desmoceras kossmati.

(b) Lower Member [IIb], about $130 \mathrm{~m}$ thick, consists of muddy fine-grained sandstones with numerous calcareous nodules. As leading fossils are abundant Desmoceras (Pseudouhligella) japonicum, Mantelliceras n. sp. (Lower part only), Calycoceras orientale, $C$. asiaticum (these two species upper part only) and Inoceramus concentricus nipponicus. In addition to them, pelecypods of Acanthotrigonia pustulosa, Ac. longiloba, Pterotrigonia hokkaidoana, Pt. brevicula, Cucullaea ezoana, Anthonia japonica, Callista pseudoplana, Crenella gyliakiana, etc. are commonly found especially in the lower part.

(c) Middle Member [IIc], $60 \mathrm{~m}$ thick, comprises massive siltstones which frequently contain large and small calcareous nodules. Calycoceras naviculare, Desmoceras (Pseudouhligella) japonicum and Inoceramus concentricus nipponicus occur at the lower and middle parts. In addition, Kanabiceras septemseriatum, Sciponoceras kossmati and Inoceramus cf. labiatus are found at the uppermost part.

(d) Upper Member [IId] is made up of coarse- to fine-grained graywackes. Calcareous nodules are commonly contained in some beds. Glauconitic sandstone beds are sometimes intercalated in addition to some thin beds of pebble conglomerate and layers of pebbles. As a sedimentary feature lobal ripple mark is occasionally observed on sandstone beds. Inoceramus hobetsensis and Tragodesmoceroides subcostatus, pelecypods of Heterotrigonia subovalis, Steinmanella (Yeharella) ainuana, Glycymeris hokkaidoensis, Cucullaea ezoana, Callista pseudoplana, etc. are commonly found although they occur in certain particular beds. Especially, glycymerids, cucullaeids and Callista are abundant in conglomeratic parts, together with shell fragments of inocerami.

(3) Distribution. The outcrop of the Mikasa Formation in the Ikushumbets anticline is schematically shown in Fig. 2. The outcrop belt of the Mikasa Formation in the studied area is for convinience divided into the three parts: western wing, southwestern wing and eastern wing (Fig. 4).

(4) Lithofacies. Vertical and lateral variations of lithofacies of the Mikasa Formation in the studied area are concisely described in the following:

(a) Vertical variation: In the section along the Ikushumbets Valley (eastern wing) (Fig. 5, adopted from Matsumoto, 1959, pl. 7) the Upper Member IId is mainly composed of sandstone and conglomerate, whereas the whole of the rest Members Ila to IIc is predominated by siltstone. In term of the sandstone plus conglomerate/ siltstone ratio which is replaced by the coarse clastics/silt ratio in other places of the paper, it is about 3 in the former member, while in the latter about 0.9 .

(b) Lateral variation: A remarkable change of lithofacies is recognized laterally in the Mikasa Formation, as is concisely shown in the serial columnar sections in Figs. 5 and 6 .

So far as the exposed strata are concerned, the coarse clastics/silt ratio in each of the examined sections (Figs. 3 and 5 ) is estimated as follows: 


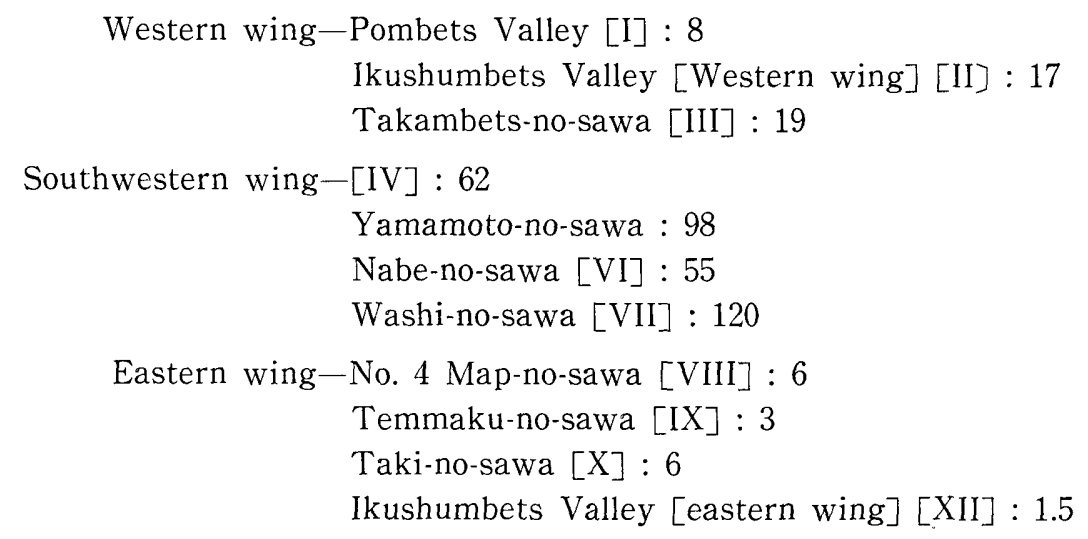

Another fact to be noted is that in the Mikasa Formation on the western wing thin coal seams are contained, bearing tiny lumps of amber, and especially redbeds are intercalated at a few horizons in the sequence along the Pombets Valley (Fig. 6).

In brief, there is a considerable difference in lithological constituents between the eastern and the western to southwestern wings of the Ikushumbets anticline. Namely, on the former wing the mudstone or siltstone occupies a considerable part, whereas on the latter the conglomerate and sandstone are much predominant, being sometimes accompanied by coal seams and redbeds.

(5) Sedimentary features. Noteworthy sedimentary features are as follows: For one thing, conglomeratic parts contain in general molluscan fossils of such shallow-sea elements as "Trigonia", Glycymeris, Callista, Ostrea, etc. Conglomerates are as a rule made up of well-abraded pebbles and cobbles which consist mainly of red and milky white cherts, fine- to medium-grained sandstones and hornfelsic shale, and subordinately of andesite, liparite, porphyrite, diabase, granitic rocks and aplite.

Calcareous nodules are abundant in siltstone facies, measureing some $10 \mathrm{~cm}$ to $1 \mathrm{~m}$, and most of them bear fossils of ammonoids, inocerami and other molluscs, usually together with plant drifts. Sandstone also includes calcareous nodulous parts which look umber when weathered, but it is mostly barren of fossils.

Lobal ripple marks are not uncommonly observed on the bedding planes of sandstones.

\section{Petrology}

\section{A. Method of study}

(1) Material. Sampling of sandstone specimens was made to ensure adequate geographic and stratigraphic coverage as effectively as possible from outcrops according to the following scheme: to collect one specimen from one bed and at least two samples either in the case the sandstone bed is very thick or lithologic variation is distinct with one bed. Especially, sampling was confined to the parts free from calcareous nodules. In addition to sandstone specimens, sandy siltstones and pebbles of conglomerates were collected as supplementaries. Geographical and stratigraphical positions from which the examined specimens came are tabulated on Table 1 and 


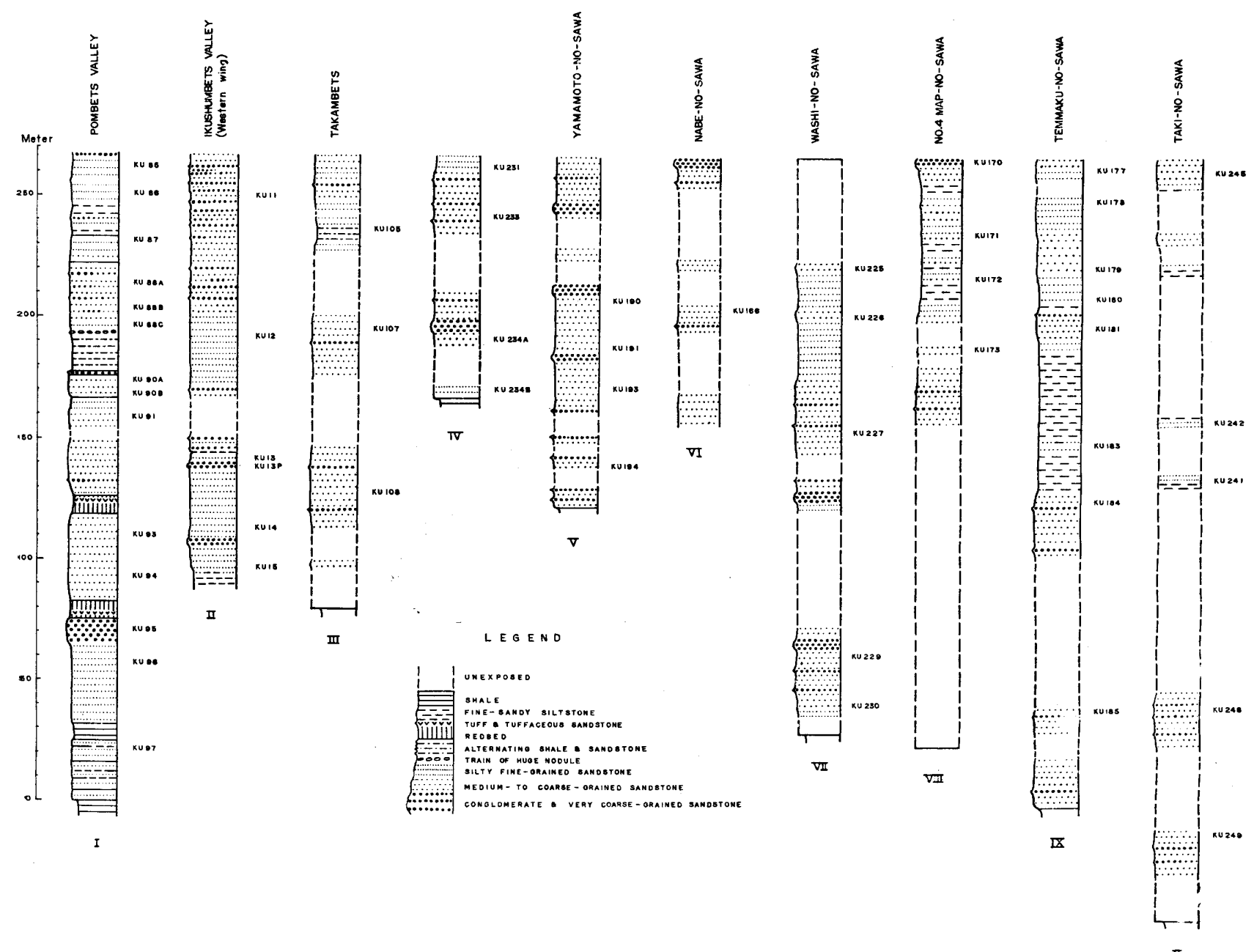

Fig. 6. Columnar sections of the Mikasa Formation along the selected routs in the Ikushumbets anticlinal area, showing positions of the rock samples. (The columnar section I along the Pombets Valley is drawn after Matsumoto's unpublished data by his courtesy).

Sections I to III : western wing, sections IV to VII : southwestern wing, sections VIII to X: eastern wing.

Explanation of lithology in the columnar section: $1:$ mudstone, $2:$ tuff and tuffaceous sandstone, $3:$ finesandy siltstone, $4:$ silty fine-grained sandstone, $5:$ medium- to coarse-grained sandstone, 6 : conglomerate and very coarse-grained sandstone, $7:$ alternating shale and sandstone, and 8 : shale. 
Table 1. List of specimens used.

\begin{tabular}{|c|c|c|c|c|}
\hline $\begin{array}{l}\text { Specimen } \\
\text { No. }\end{array}$ & $\begin{array}{l}\text { Stratigraphic } \\
\text { positions* }\end{array}$ & Locality & $\begin{array}{l}\text { Remarks (colour; } \\
\text { grain size ; others) }\end{array}$ & Collectors \\
\hline KU11 & II & $\begin{array}{l}\text { Ikushumbets Valley, } \\
\text { Mikasa City [Western } \\
\text { wing](三笠杖幾春别川) } \\
\text { [II] }\end{array}$ & 10 GY $5 / 2$; c. & H. OKADA \\
\hline KU12 & II & Do. & 5 GY $5 / 2$; f. & - \\
\hline KU13 & II & Do. & $5 \mathrm{GY} 5 / 2 ; \mathrm{c}$. & $-\cdots$ \\
\hline KU13p & II & Do. & $\begin{array}{l}\text { Rounded sandstone } \\
\text { pebble }\end{array}$ & $-\ldots$ \\
\hline KU14 & II & Do. & 5 GY $5 / 2 ; c$ & $\longrightarrow$ \\
\hline KU15 & II & Do. & 10 GY $3 / 2$; v. f. & - \\
\hline KU16 & I & Do. & & \\
\hline KU17 & $\begin{array}{l}\text { I(Yunosawa } \\
\text { Sandstone) }\end{array}$ & $\begin{array}{l}\text { Ikushumbets Valley } \\
\text { [Eastern wing }][\mathrm{XII}]\end{array}$ & $5 \quad$ B $6 / 2 ; f$ & - \\
\hline KU18 & I (Do.) & Do. & $10 \mathrm{GY} \mathrm{5/2; \textrm {m } .}$ & - \\
\hline KU19 & I (Do.) & Do. & 5 BG 5/2; m. & - \\
\hline KU21 & I (Do.) & Do. & $5 \quad$ B $6 / 2 ; \mathrm{m}$. & - \\
\hline KU22 & I (Do.) & Do. & 5 B $6 / 2 ; \mathrm{m}$. & \\
\hline KU23 & I (Do.) & Do. & $5 \quad$ B $6 / 2 ; \mathrm{m}$. & \\
\hline KU25 & I (Do.) & Do. & 5 BG $6 / 2 ; \mathrm{m}$. & \\
\hline KU26 & I (Do.) & Do. & 5 BG 6/2; m. & $\cdots$ \\
\hline KU27 & I (Do.) & Do. & $5 \quad \mathrm{~B} 6 / 2 ; \mathrm{m}$ & - \\
\hline $\mathrm{KU} 28$ & I (Do.) & Do. & $5 \mathrm{BG} 5 / 2 ; \mathrm{m}$ & \\
\hline KU29 & I (Do.) & Do. & $5 \quad \mathrm{~B} 6 / 2 ; \mathrm{m}$ & \\
\hline KU31 & I (Do.) & Do. & & \\
\hline KU32 & I (Do.) & Do. & 5 BG $5 / 2 ; c$ & $\longrightarrow$ \\
\hline KU35 & I & Do. & N $3 ;$ v.f. & $\begin{array}{l}\text { T. Matsumoto } \\
\text { \& H. OKADA }\end{array}$ \\
\hline IK1096a & I & Do. & 5 BG $5 / 2$; f. & T. Matsumoto \\
\hline KU36 & I & Do. & $5 \quad$ G $5 / 2 ; f$ & $\begin{array}{l}\text { T. MATSUMOTO } \\
\text { \& H. OKADA }\end{array}$ \\
\hline KU37 & I & Do. & $10 \mathrm{GY} 5 / 2 ; \mathrm{f}$ &,-- \\
\hline IK1096d & I & Do. & $10 \mathrm{GY} 5 / 2 ; \mathrm{m}$ & T. Matsumoto \\
\hline KU38 & I & Do. & 5 GY 5/2; m. & $\begin{array}{l}\text { T. MATSUMOTO } \\
\text { \& H. OKADA }\end{array}$ \\
\hline KU39 & I & Do. & 10 GY $5 / 2 ; \mathrm{f}$ &,-- \\
\hline KU42 & I & Do. & $5 \quad$ G 4/1; v.f. & $\longrightarrow,-$ \\
\hline IK1056e & IIa & Do. & $\begin{array}{l}5 \mathrm{BG} 5 / 2 ; \mathrm{m} \\
\text { tuffaceous }\end{array}$ & T. Matsumoto \\
\hline KU44 & IIa & Do. & $\begin{array}{l}5 \underset{\text { G } 4 / 1 ; \mathrm{f} . ; \text { bearing }}{\text { gastropods }}\end{array}$ & $\begin{array}{l}\text { T. MATSUmoto } \\
\text { \& H. OKADA }\end{array}$ \\
\hline KU45 & IIb & Do. & $\begin{array}{l}\mathrm{N} 3 \text {; v.f.; } \\
\text { bearing drifts }\end{array}$ & $\longrightarrow, \square$ \\
\hline KU51 & IIb & Do. & $5 \quad \mathrm{G} 4 / 1 ; \mathrm{f}$ &,-- \\
\hline KU52 & IIb & Do. & $\begin{array}{l}5 \mathrm{G} 4 / 1 ; \mathrm{f} . ; \text { bearing } \\
\text { gastropods }\end{array}$ &,-- \\
\hline
\end{tabular}

\footnotetext{
* Regarding stratigraphic divisions, Fig. 5 should be referred to.
} 
Continued Table 1.

\begin{tabular}{|c|c|}
\hline KU53 & IIb \\
\hline KU58 & IIb \\
\hline KU59 & IId \\
\hline KU60 & IId \\
\hline KU61 & IId \\
\hline KU62 & IId \\
\hline KU63 & IId \\
\hline KU64 & IId \\
\hline KU65 & IId \\
\hline KU66 & IId \\
\hline KU67 & IId \\
\hline KU68 & IId \\
\hline KU69 & IId \\
\hline KU70 & IId \\
\hline IK971 & IIIa \\
\hline IK976 & IIIa \\
\hline IK1263 & III \\
\hline IK1121 & III \\
\hline KU85 & II \\
\hline KU86 & II \\
\hline KU87 & II \\
\hline KU88A & II \\
\hline KU88B & II \\
\hline KU88C & II \\
\hline KU90A & II \\
\hline KU90B & II \\
\hline KU91 & II \\
\hline KU93 & II \\
\hline KU94 & II \\
\hline KU96 & II \\
\hline KU97 & II \\
\hline KU105 & II \\
\hline KU107 & II \\
\hline KU108 & II \\
\hline KU119 & II \\
\hline
\end{tabular}

Do.
Do.
Do.
Do.
Do.
Do.
Do.
Do.
Do.
Do.
Do.
Do.
Do.
Do.
Do.
Do.
Kik

Kikumen-zawa, a tributary of the upper course of the Ikushumbets (Valley) (菊面沃)

Ban-no-sawa, ditto (盤ノ沢)

Pombets Valley, Mikasa City (奔別川) [I]

Do.

Do.

Do.

Do.

Do.

Do.

Do.

Do.

Do.

Do.

Do.

Do.

Takambets, Mikasa City (多寒别) [III]

Do.

Do.

A small branch of the Ikushumbets Valley, south of the Katsurazawa Electric Station (桂沢発電所) [XI]
5 G 4/1; v.f.; bearing drifts and pelecypods

5 G 4/1;f.

10 GY 6/2; m.; pyritiferous

5 G 4/1; v.f.

5 G 4/1; f.

5 G $4 / 1 ; \mathrm{m}$.

$5 \quad \mathrm{G} 4 / 1$; .

5 G 4/1; v.f. $\mathrm{N} \quad 3$; v.f,

$5 \mathrm{G} \mathrm{4/1;m}$.

$5 \mathrm{G} 5 / 2 ; \mathrm{m}$.

$10 \mathrm{GY} 5 / 2$; m.

$10 \mathrm{GY} 5 / 2$; m.

5 B $5 / 1 ; \mathrm{m}$.

glauconitic

$$
\text { m. ; }
$$

m.

$\mathrm{m}$.

m.

10 GY 5/2; f.

5 GY 5/2; f.

10 GY 5/2; f.

5 G $5 / 2$; v.f.; bearing drifts

5 G 5/2; f.

$5 \mathrm{G} 5 / 2$; f.

$5 \mathrm{G} 5 / 2 ; \mathrm{m}$.

5 G 5/2;m.

$5 \mathrm{G} 5 / 2 ; \mathrm{m}$.

$5 \mathrm{Y} 5 / 6$; m.;

weathered

5 GY $5 / 2$; m.

5 GY $5 / 2$; v.f.

5 G 5/2; f.

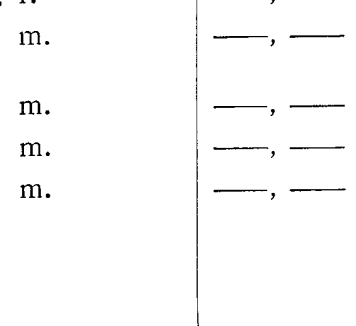


Continued Table 1.

\begin{tabular}{|c|c|c|}
\hline KU141 & II & $\begin{array}{l}\text { Sentaro-no-sawa, } \\
\text { northwest of Tomatsu, } \\
\text { Mikasa City (们太郳 }, \\
\text { 沢, 唐松) [XIII] }\end{array}$ \\
\hline KU142 & II & Do. \\
\hline KU143 & II & Do. \\
\hline KU144 & II & Do. \\
\hline KU147 & II & Do. \\
\hline KU166 & II & $\begin{array}{l}\text { Nabe-no-sawa, north of } \\
\text { Miruto, Kurisawa- } \\
\text { machi, Sorachi-gun } \\
\text { (空知郡栗沢町流渡, } \\
\text { 鍋 } / \text { 沢) [VI] }\end{array}$ \\
\hline KU170 & II & $\begin{array}{l}\text { No. } 4 \text { Map-no-sawa, east } \\
\text { of Miruto(マップノ沢) } \\
\text { [VIII] }\end{array}$ \\
\hline KU171 & II & Do. \\
\hline KU172 & II & Do. \\
\hline KU173 & II & Do. \\
\hline KU177 & II & $\begin{array}{l}\text { Temmaku-no-sawa, } \\
\text { northeast of Miruto } \\
\text { (テンマクノ沢) [IX] }\end{array}$ \\
\hline KU178 & II & Do. \\
\hline KU179 & II & Do. \\
\hline KU180 & II & Do. \\
\hline KU181 & II & Do. \\
\hline KU183 & II & Do. \\
\hline KU184 & II & Do. \\
\hline KU185 & II & Do. \\
\hline KU189 & II & $\begin{array}{l}\text { Yamamoto-no-sawa, } \\
\text { about } 3.4 \mathrm{~km} \text { north of } \\
\text { Miruto (山本ノ沢) }[\mathrm{V}]\end{array}$ \\
\hline KU190 & II & Do. \\
\hline KU191 & II & Do. \\
\hline KU192 & II & Do. \\
\hline KU193 & II & Do. \\
\hline KU194 & II & Do. \\
\hline KU225 & II & $\begin{array}{l}\text { Washi-no-sawa, Miruto } \\
\text { (謷)沢) [VII] }\end{array}$ \\
\hline KU226 & II & Do. \\
\hline KU227 & II & Do. \\
\hline KU228 & II & Do. \\
\hline KU229 & II & Do. \\
\hline KU230 & II & Do. \\
\hline KU231 & II & $\begin{array}{l}\text { A valley, north of Onko- } \\
\text { no-sawa, ca. } 4.7 \mathrm{~km} \\
\text { north of Miruto (オン } \\
\text { コノ沢) [IV] }\end{array}$ \\
\hline KU233 & II & Do. \\
\hline
\end{tabular}

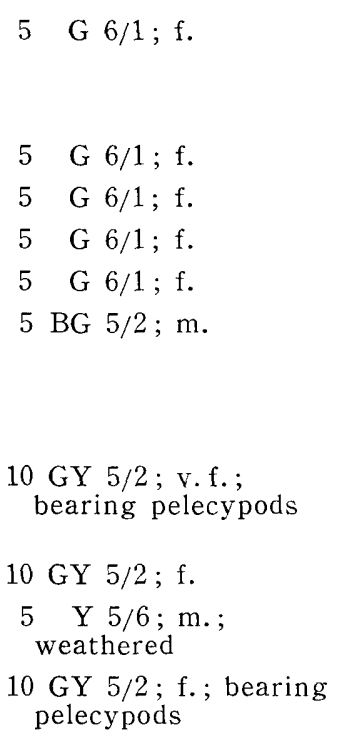

5 BG 5/2; m.

10 GY $5 / 2$; f.

5 G $5 / 2$; v.f.; bearing drifts

10 GY $5 / 2$; v.f.

$10 \mathrm{GY} 5 / 2$; v.f.

10 GY $5 / 2$; f.

5 B $5 / 1 ; \mathrm{m}$.

$10 \mathrm{G} 6 / 2 ; \mathrm{m}$.

$10 \mathrm{G} 6 / 2$; f.

$10 \mathrm{G} 6 / 2$; f.

5 B $6 / 2 ; \mathrm{m}$.

$10 \mathrm{G} 6 / 2 ; \mathrm{m}$.

$5 \quad$ G $5 / 2$; f.; bearing pelecypods

5 GY $7 / 2 ; \mathrm{m}$.

$5 \mathrm{G} 5 / 2 ; \mathrm{m}$.

$10 \mathrm{G} 6 / 2 ; \mathrm{m}$.

10 G 6/2;f.

5 GY $7 / 2$; m.

5 GY $7 / 2$; m.

5 GY 7/2; m.
H. OKADA

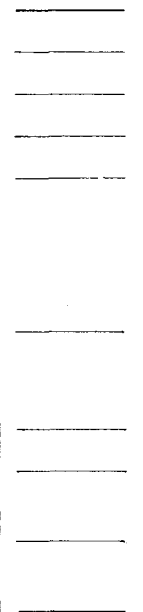


Continued Table 1.

\begin{tabular}{|c|c|c|c|c|}
\hline KU234A & II & Do. & 5 G $7 / 2$; v.f. & \\
\hline KU234B & II & Do. & $\mathrm{G} 7 / 2 ; \mathrm{m}$ & \\
\hline KU241 & II & $\begin{array}{l}\text { Taki-no-sawa, ca. } 5.8 \mathrm{~km} \\
\text { south of Ikushumbets, } \\
\text { Mikasa City (滰ノ沢) } \\
\text { [X] }\end{array}$ & & \\
\hline KU242 & II & Do. & 10 GY $5 / 2$; f. & \\
\hline KU245 & II & Do. & $10 \mathrm{G} 6 / 2 ; \mathrm{m}$. & \\
\hline KU248 & II & Do. & & \\
\hline KU249 & II & Do. & $10 \mathrm{G} 6 / 2 ; \mathrm{m}$. & - \\
\hline \multirow[t]{4}{*}{ Notes } & 1) & \multicolumn{3}{|c|}{ Specimen number has a prefix KU except for the specimen with a prefix IK } \\
\hline & 2) & \multicolumn{3}{|c|}{$\begin{array}{l}\text { Stratigraphic position of the examined specimen is shown by the Roman } \\
\text { numerals after the scheme proposed by MATSUmoto (1959) (see Fig. 5). }\end{array}$} \\
\hline & 3) & \multicolumn{3}{|c|}{$\begin{array}{l}\text { Locations of valley and sawa (or zawa) [Jap.: small valley] should be referred } \\
\text { to Fig. } 3 \text {. }\end{array}$} \\
\hline & 4) & \multicolumn{3}{|c|}{ Rock colour is after GODDARD [Chairman] (1951). } \\
\hline
\end{tabular}

illustrated in Figs. 4, 5 and 6.

The material used in this study is all preserved in the Department of Geology, Kyushu University, Fukuoka.

(2) Procedure. Standard methods of petrologic analyses (see OKADA, 1960b) are applied for each sample.

\section{B. Sandstone types}

The examined sandstones are represented by the graywacke and the subgraywacke clans on the basis of Pettijohn's scheme of classification (PETTIJohn, 1957, Table 48) (see Fig. 10 and Table 2 and 3).

The graywacke sandstones with clay matrix of more than 15 percent are developed on the eastern wing of the Ikushumbets anticlinal area. The subgraywacke is characteristic of the western to southwestern wing.

This type may be also regarded as washed graywacke, a product of current agitation at or near the site of sedimentation.

The significance of these two types of sandstones is discussed in Chapter $\mathrm{V}$ in more detail.

\section{Texture and maturity}

(1) Grain-size distribution. The graywacke sandstones are characterized by bimodal to polymodal distribution of grain size, as is shown by a specimen KU91 in Fig. 7. In a striking contrast to the above, the subgraywacke sandstones show a unimodal distribution, as is shown by specimens KU 185 and KU 233 in Fig. 7. Sorting values of the measured subgraywackes are 1.10 to 1.22 and are thus comparable to beach sands. This fact suggests that they were to a great extent subject to wave agitation. Some well sorted examples are exhibited in Fig. 8. 


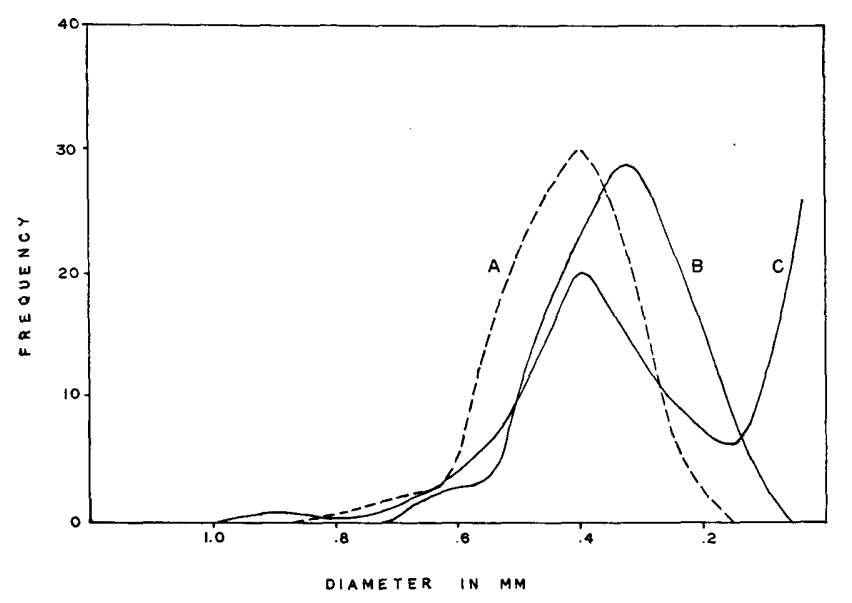

Fig. 7. Representative examples of grain-size distribution of sandstones. A : Sp. No. KU 185, B: Sp. No. KU 233, C : Sp. No. KU 91.

(2) Roundness. The average roundness of sand-grains of each specimen is subdivided into the five classes, according to PetTijohn's scale (1957, pp. 58-59): A-angular, B-subangular, C-subrounded, D-rounded, E-well rounded. It is interesting that sandstones on the eastern wing show the average roundness of $B$, whereas those on the western and the southwestern wings show that of C to D (see Tables 2 and 3).

(3) Maturity. The maturity of sediments is expressed in terms of mineralogical and textural characters, and these two characters are as a rule interrelated, although a peculiar case is exceptionally known that even texturally mature sediments are mineralogically immature*

The textural maturity of sediments is

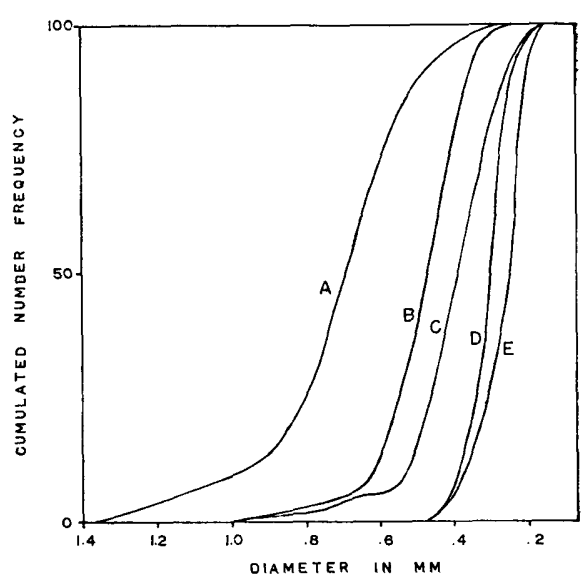

Fig. 8. Cumulative curves showing some well-sorted examples. A: Sp. No. KU 166, B : Sp. No. KU 185, C : Sp. No. KU 233, D : Sp. No. KU 190, E : Sp. No. KU 177. defined by the three factors, i.e. clay content, sorting and roundness (FoLK, 1951), each of which is concisely described in the preceding pages.

The mineralogical maturity is in general measured by the ratio of quartz/feldspar or quartz plus chert/feldspar plus rock fragments (PETTiJoHN, 1957, pp. 509-510). Even from a rough estimation the coarse clastics in the investigated area are evidently prevailed by older sedimentary rock fragments. That is to say, the sediments are mainly derived from a supracrustal complex poor in feldspar. Therefore, it seems to

* For instance, serpentine sandstones of the Miocene sediments in Hokkaido (Matsumoto et al., 1963; OKADA, 1964). 
be appropriate in the present case to introduce the ratio of quartz plus chert/feldspar plus rock fragments as a mineralogical maturity index rather than the ratio of quartz/feldspar.

On the eastern wing the ratio in the examined specimens is estimated as about 1.9 , although it varies between 0.71 and 4.35. To the contrary, on the western wing the average value is about 3.3 and on the southwestern about 2.4. Therefore, the sandstones on the western to southwestern wing are more mature than those on the eastern. This fact agrees well with the natures shown by sorting and roundness.

\section{Mineral composition}

\section{Major constituents}

Six components are taken as the major constituents of sandstones; quartz, chert, feldspar, non-cherty rock fragments, clay matrix and calcite cement. Their frequency in occurrence is tabulated in Tables 2 and 3 , and compositional tendency of sandstones is shown in Fig. 9 and 10.

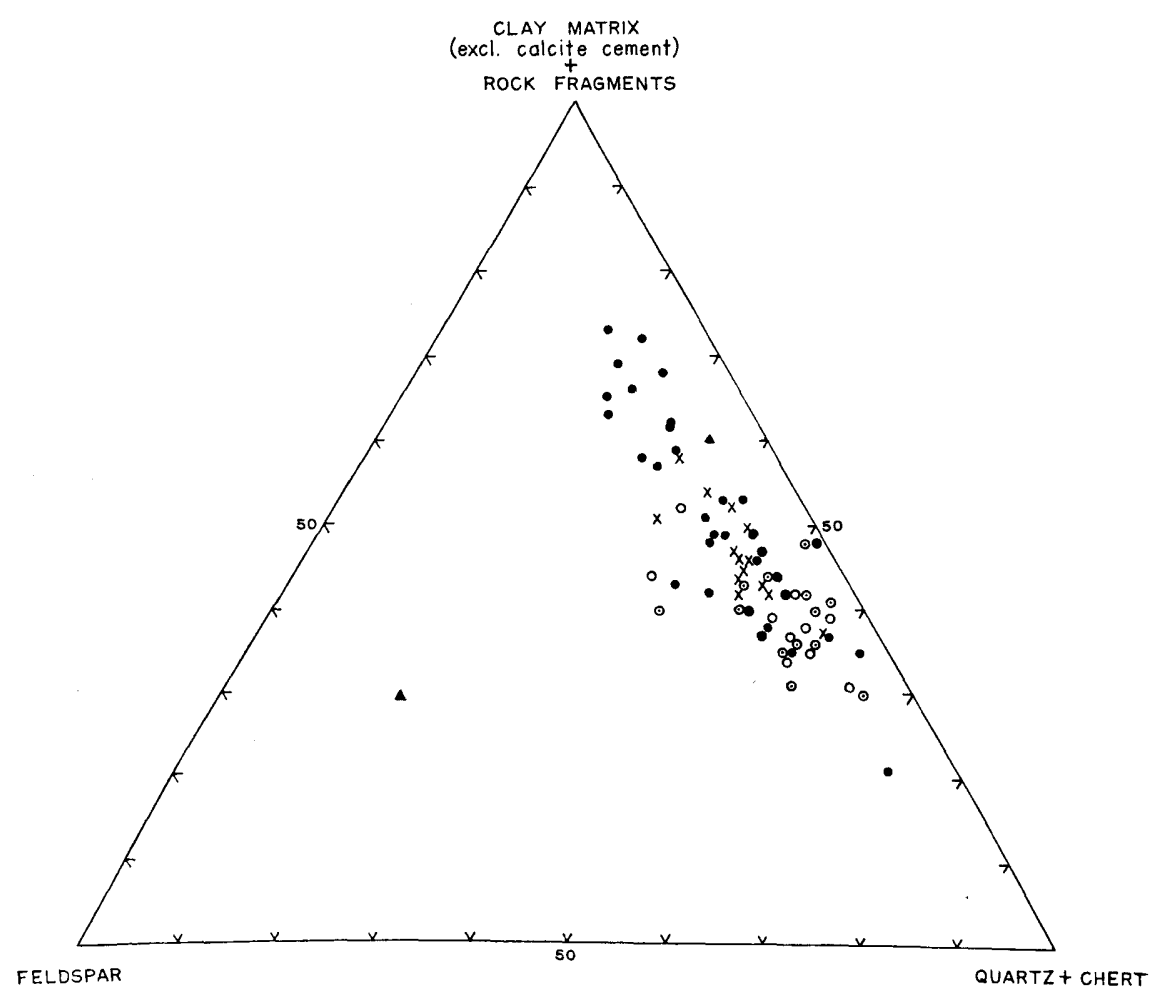

Fig. 9. Compositional diagram of the Cretaceous sandstones.

- - Sandstones of the Mikasa Formation on the eastern wing. $\bullet$ - Sandstones of the Mikasa Formation on the western wing. O-Sandstones of the Mikasa Formation on the southwestern wing. $\times$-Sandstones of the lower part [1] of the Middle Yezo Group. $\Delta$-Sandstones of the Upper Yezo Group. 
Following is a brief note on each of the major constituents :

(1) Quartz. Quartz is one of the most important constituents of sandstones in the studied area. In an exceptional case where the quartz content is only 7 percent of the bulk (e.g. KU 166), chert serves as complementary of quartz in amount.

In general quartz is subdivisible into the following varieties: igneous quartz, metamorphic quartz, vein quartz and microcrystalline quartz. Among these varieties, igneous quartz is predominant, many grains of which are considered to be of plutonic origin, although high-quartz of volcanic origin is not uncommon in occurrence. Metamorphic quartz is readily identified when each part of the grains bounded with complicate sutures displays intense undulose extinction. Its occurrence is not significant. Vein quartz is also rarely met with.

(2) Chert or microcrystalline quartz. Chert fragments occur with a considerable high percentage (Pl. 1, Figs. 1, 2, 4-7 ; Pl. 2). Generally chert grains are somewhat more rounded than other mineral grains. They consist of milky white, dark grey and reddish varieties. Many of the grains are crossed by veinlets which seem to suggest fracturing in the mother rock. Radiolarian remains are commonly met with (Pl. 2, Fig. 1c).

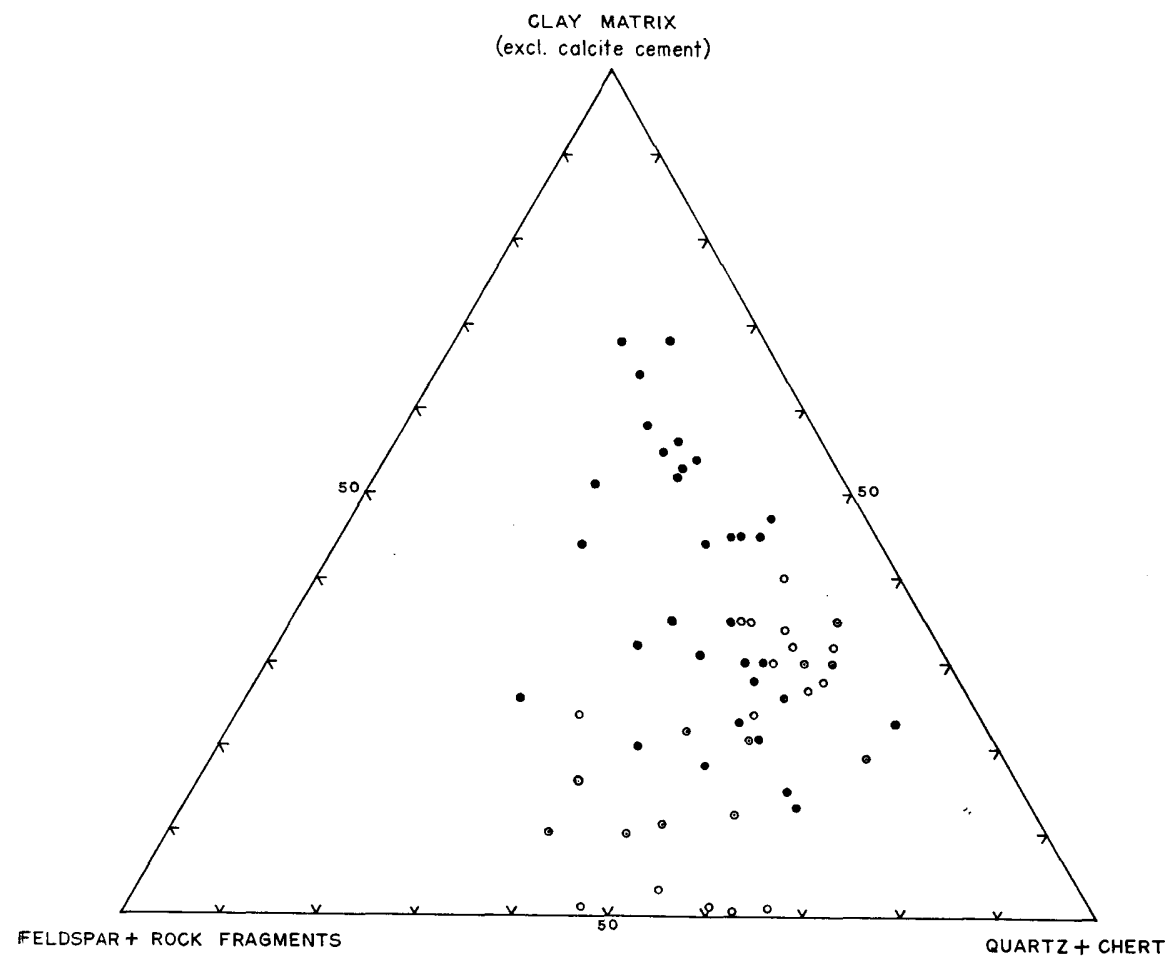

Fig. 10. Diagram showing differentiation of the Mikasa sandstone between the eastern and the western to southwestern wing.

-Sandstones from the eastern wing.

-- Sandstones from the western wing.

O-Sandstones from the southwestern wing. 
(3) Feldspar. Potassic feldspar and plagioclase mainly of andesine are predominant, of which the former is a little commoner than the latter, being accompanied with microcline.

A specimen of the Upper Yezo Group [IK 1263] differs from those of the Mikasa Formation (Fig. 9; Pl. 1, Fig. 3).

(4) Rock fragments. They are rather variable in frequency. They consist of andesite, spherulitic acid to intermediate tuff, porphyrite, sandstone, slate, etc.

(5) Clay matrix. It is mostly altered into chlorite and/or sericite.

(6) Calcite. Sediments in the studied area are more or less calcareous. Sandstone is not exceptional, either. Sandstone of the subgraywacke clan is generally cemented with sparry calcite instead of clay matrix (Pl. 1, Figs. 5, 7; Pl. 2, Figs. 1, 2, 4, 6). In addition, small parts of feldspars, rock fragments and clay matrix are replaced by calcite.

\section{Heavy minerals}

a. Heavy mineral content

Although heavy mineral contents of the examined specimens range from 0.06 to 3.36 percent, most of them are rather insistent in heavy mineral content, showing less than 1 percent. On the eastern wing the content is somewhat lesser than that on the western and the southwestern wings.

b. Identified mineral species

The identified fifteen transparent minerals and six iron minerals are listed on Tables 4 and 5, with their abundance in the examined samples. Some brief notes are given below on each of them:

(1) Zircon. Euhedral zircon is almost equal with or lesser than abraded one in frequency. In both cases zircon is divisible into colourless, pale pink and purple varieties according to colours, of which egg-shaped purple variety shows a particular pattern of distribution. Namely it horizontally occurs more abundantly in the
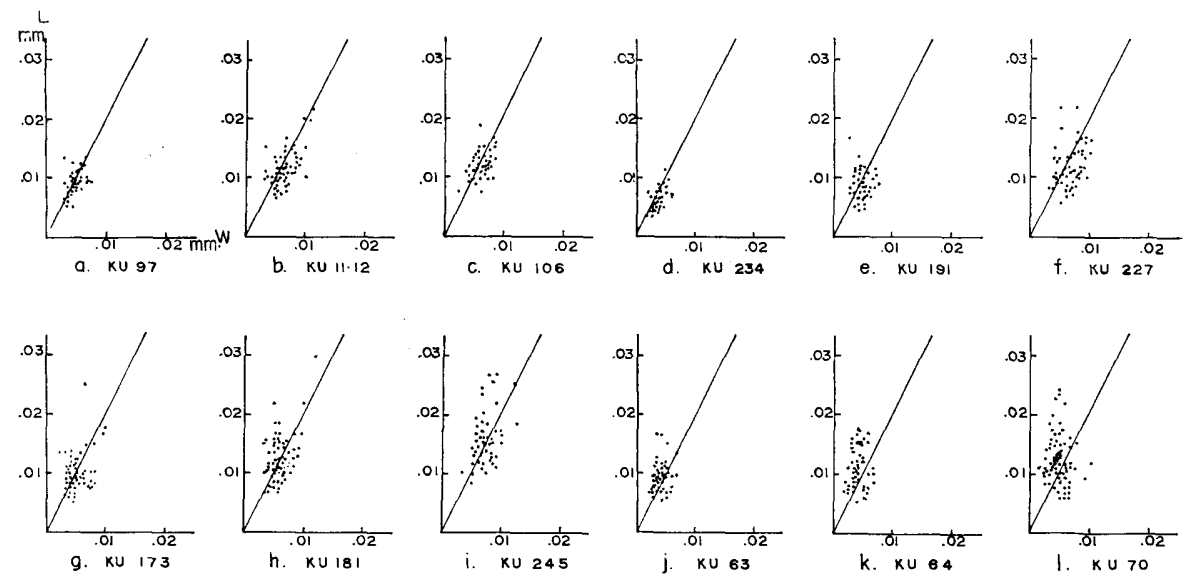

Fig. 11. Elongation ratio of zircons from some selected sandstones. Note the difference between the eastern and the western to southwestern wing. Zircons from the former (i-1) are slenderer than those of the latter $(a-h)$. 
Table 2. Major constituents of the sandstones of the Cretaceous exposed along the Ikushumbets Valley.

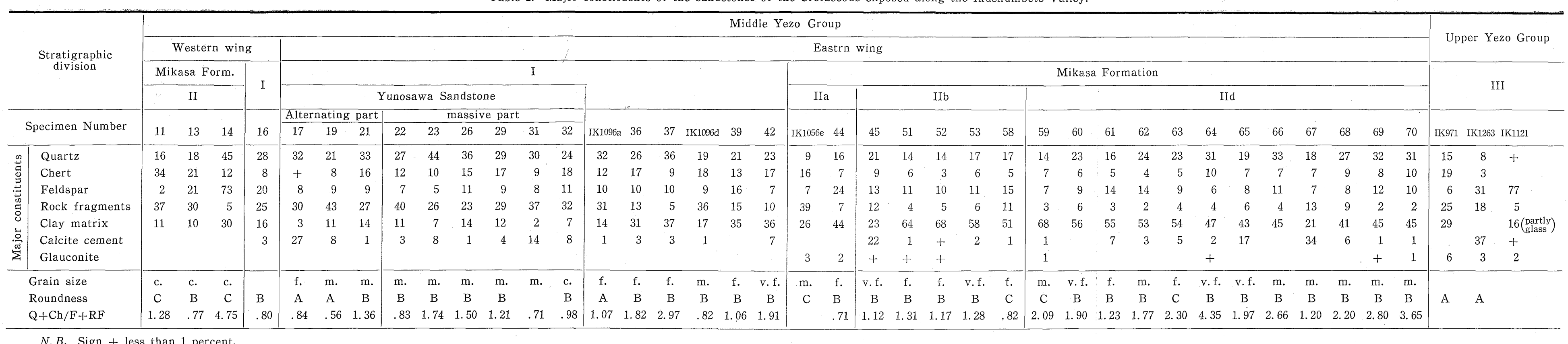

B. Sign + less than 1 percent.

From the Specimen Number a prefix KU is omitted except for in the specimen with IK.

Table 3. Major constituents of the Mikasa sandstones.

\begin{tabular}{|c|c|c|c|c|c|c|c|c|c|c|c|c|c|c|c|c|c|c|c|c|c|c|c|c|c|c|c|c|c|c|c|c|c|c|}
\hline \multirow{3}{*}{$\begin{array}{c}\text { Locality } \\
\text { Specimen Number }\end{array}$} & \multicolumn{9}{|c|}{ Western wing } & \multicolumn{11}{|c|}{ Southern wing } & \multicolumn{14}{|c|}{ Eastern wing } \\
\hline & \multicolumn{6}{|c|}{$\begin{array}{c}\text { Pombets Valley } \\
{[I]}\end{array}$} & \multicolumn{3}{|c|}{$\begin{array}{c}\text { Takambets } \\
{[\mathrm{III}]}\end{array}$} & \multicolumn{3}{|c|}{ [IV] } & \multicolumn{3}{|c|}{$\begin{array}{c}\text { Yamamoto-no-sawa } \\
{[\mathrm{V}]}\end{array}$} & \multirow{2}{*}{$\begin{array}{l}{[\mathrm{VI}]} \\
166\end{array}$} & \multicolumn{4}{|c|}{$\begin{array}{c}\text { Washi-no-sawa } \\
{[\mathrm{VII}]}\end{array}$} & \multicolumn{2}{|c|}{$\begin{array}{l}\text { Map-no-sawa } \\
\text { [VIII] }\end{array}$} & \multicolumn{7}{|c|}{$\begin{array}{c}\text { Temmaku-no-sawa } \\
{[\mathrm{IX}]}\end{array}$} & \multicolumn{4}{|c|}{$\begin{array}{c}\text { Taki-no-sawa } \\
{[\mathrm{X}]}\end{array}$} & \multirow{2}{*}{$\begin{array}{l}{[\mathrm{XI}]} \\
119\end{array}$} \\
\hline & 87 & $90 \mathrm{~A}$ & $90 \mathrm{~B}$ & 91 & 93 & 94 & 105 & 107 & 108 & 231 & 233 & $234 \mathrm{~B}$ & 190 & 193 & 194 & & 225 & 226 & 227 & 229 & 172 & 173 & 177 & 178 & 179 & $181 \quad 1$ & 18318 & $184 \quad 1$ & 185 & 242 & 245 & 248 & 249 & \\
\hline Quartz & 33 & 47 & 35 & 31 & 36 & 26 & 47 & 29 & 40 & 20 & 20 & 31 & 38 & 34 & 30 & 29 & 42 & 41 & 29 & 25 & 38 & 3 & 25 & 36 & 44 & 44 & 34 & 42 & 16 & 41 & 37 & 20 & 34 & 34 \\
\hline Chert & 24 & 19 & 20 & 24 & 18 & 20 & 9 & 24 & 8 & 8 & 19 & 21 & 19 & 23 & 25 & 19 & 5 & 10. & 6 & 12 & 7 & 7 & 11 & 8 & 7 & 7 & 5 & 7 & 29 & 5 & 14 & 42 & + & 21 \\
\hline Feldspar & 12 & 5 & 9 & 5 & 11 & 11 & 3 & 5 & 8 & 10 & 4 & 6 & 7 & 4 & 8 & 4 & 13 & 10 & 6 & 6 & 11 & 7 & 9 & 7 & 12 & 7 & 8 & 7 & 1 & 8 & 11 & 3 & 12 & 10 \\
\hline 焉 & 19 & 9 & 6 & 14 & 14 & 20 & 6 & 18 & 4 & 22 & 19 & 12 & 9 & 7 & 6 & 21 & 5 & 5 & 22 & 29 & 8 & 13 & 30 & 18 & 7 & 14 & 18 & 11 & 28 & 11 & 20. & 21 & 17 & 14 \\
\hline 今ั & 12 & 19 & 30 & 26 & 21 & 22 & 35 & 24 & 40 & 19 & + & 30 & 27 & 32 & 27 & 1 & 35 & 34 & 2 & 8 & 35 & 35 & 1 & 31 & 30 & 23 & 35 & 30 & & 35 & 18 & 15 & 16 & 21 \\
\hline Calcite cement & & 1 & & & & 1 & + & & & 21 & 38 & + & & + & 4 & 26 & & 1 & 35 & 20 & & & 24 & & & + & & 3 & 26 & & & & 21 & \\
\hline Grain size & f. & $\mathrm{m}$. & m. & $\mathrm{m}$. & m. & $\mathrm{m}$. & $\mathrm{m}$. & m. & m. & $\mathrm{m}$. & $\mathrm{m}$. & $\mathrm{m}$. & f. & & m. & $\mathrm{m}$. & f. & m. & $\mathrm{m}$. & m. & m. & f. & & f. & v. f. & v. f. & & f. & $\mathrm{m}$. & f. & $\mathrm{m}$ & & m. & $\mathrm{m}$. \\
\hline & C & $\mathrm{C}$ & $\mathrm{D}$ & C & $\mathrm{D}$ & C & $\mathrm{C}$ & $\mathrm{D}$ & $\mathrm{C}$ & $\mathrm{D}$ & D & $\mathrm{B}$ & $\mathrm{D}$ & $\mathrm{D}$ & $\mathrm{C}$ & $\mathrm{D}$ & $\mathrm{C}$ & $\mathrm{C}$ & D & $\mathrm{C}$ & & & C & $\mathrm{C}$ & $\mathrm{C}$ & $\mathrm{C}$ & B & C & D & c & B & $\mathrm{C}$ & B & B \\
\hline $\mathrm{Q}+\mathrm{Ch} / \mathrm{F}+\mathrm{RF}$ & 1.84 & 4.71 & 3.67 & 2.90 & 2.161. & 1.48 & 6.22 & 2. 31 & 4.00 & 0.86 & 1.72 & 3.02 & 3.54 & 4.77 & 2. 20 & 1.93 & 2.67 & 3.47 & 1. 23 & 1.03 & 2.37 & 2. 29 & 0.94 & 1.79 & 2.542 & 2.551 & $1.56 \quad 2$. & $2.72 \quad 1$ & 1.59 & 2.50 & 1.59 & 2.54 & 1.19 & 2.29 \\
\hline
\end{tabular}

N.B. Sign + less than 1 percent.

square brackets indicating locality is a guide index shown in Fig. 3. 
Table 4. Heavy mineral frequencies of the sandstones of the Cretaceous exposed along the Ikushumbets.

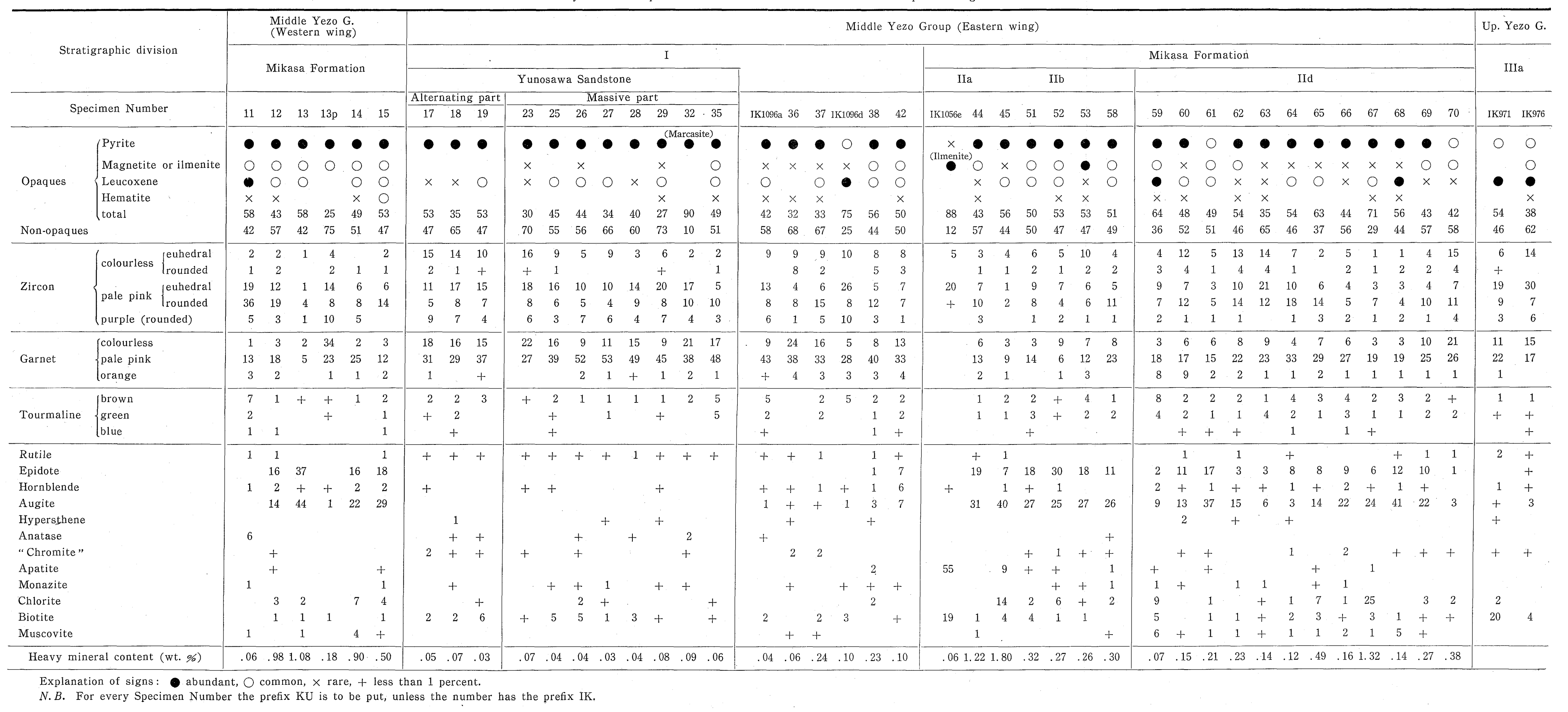


Table 5. Heavy minerals of the Mikasa sandstones

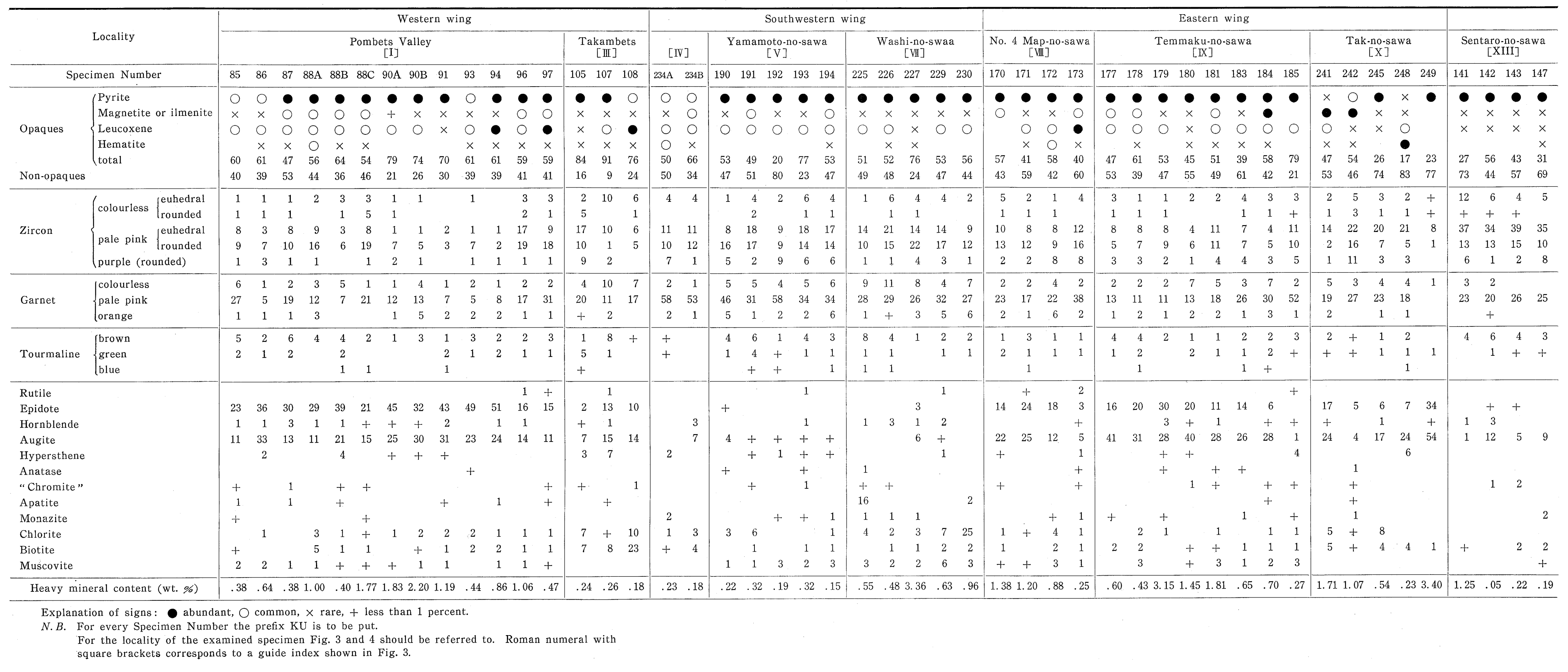


southwestern part of the anticlinal area and vertically in the lower part of the Middle Yezo Group than in other parts. This variety is considered for the most part to have been derived from older sedimentary rocks as a multi-cyclic detritus, because a sandstone pebble contains it in a considerable amount (KU 13p; Pl. 3, Fig. 1). In addition to the above, elongation of the crystal is estimated a little larger on the eastern wing than on the western and the southwestern wings (Fig. 11). Furthermore, a ratio of rounded zircon to euhedral one is higher on the western to southwestern wing than on the eastern. Outgrowth of zircon is rarely recognized.

(2) Monazite. It occurs as light yellow to yellowish brown, somewhat abraded euhedron. Generally, grains are outlined with dark border and are crowded with minute inclusions or dusts.

(3) Garnet. Colourless, pale pink and orange-coloured varieties are recognized, of which pale pink variety is prevalent and orange-coloured one is rather rare in occurrence.

According to my preliminary examination, garnet grains of various sediments seem to be identified mostly to almandite irrespective of the above recognized colours. Judging from the unit cell edge $\left(\mathrm{a}_{0}\right)$ and refractive index $(\mathrm{n})$, the grains of greyish pink garnet (5R 8/2) separated from the Mikasa sandstone [Sp. No. KU 192] are also predominated by almandite (56 to 68 percent) and accompanied with pyrope (27 to 32 percent) and a small amount of spessartine or grossular or andradite, as referred to the diagrams prepared by SRIRAmADAS (1957) (see Table 6).

Table 6. Physical properties of garnet separated from the specimen KU 192 and its possible compositions.

\begin{tabular}{c|c|c|c|c}
\hline $2 \theta$ obs. & $2 \theta$ corr. & $d(\AA)$ & $h k l$ & $\mathrm{a}_{0}$ \\
\hline 74.610 & 74.570 & 1.5979 & 640 & 11.523 \\
\hline
\end{tabular}

FeK $\alpha$ radiation; $30 \mathrm{KV}, 10 \mathrm{~mA}$; Scan. speed $1 / 4^{\circ} / \mathrm{min}$.; Time const. 5 secs. Slits $3-2-0.4 \mathrm{~mm}$.

$\mathrm{n}=1.793 \pm 0.001$

Colour $=5 \mathrm{R} 8 / 2($ greyish pink)

Possible compositions:

1) Al: 68 Py: 27 Gr: 5

2) Al:67 Py:32 An:1

3) $\mathrm{Al}: 56 \quad \mathrm{Py}: 27 \quad \mathrm{Sp}: 17$

Garnet grains usually occur as equidimensional fragments with conchoidal fractures, though dodecahedron is sometimes met with. Abraded grains are not uncommon.

As is clearly shown in Fig. 16 and on Tables 4 and 5, garnet is a common mineral throughout the whole sequence of the Yezo Group in the Ikushumbets area, and is particularly characteristic of the lower part (Unit I of MATsumoto's stratigraphic division) of the Middle Yezo Group. In the corresponding stratigraphic unit of the Yubari dome, about $12 \mathrm{~km}$ south of the southwestern periphery of the Ikushumbets anticlinal area (Fig. 1), the same rule is kept (OKADA et al. in MATsumoto 
and HARAdA, 1964; Pl. 6, Fig. 3). Within the Mikasa Formation garnet becomes abundant southwestwards.

The abundance of garnet agrees well with the predominance of coarse-grained sediments. Furthermore, it is noted that a sandstone pebble in the Mikasa Formation bears garnet in an unexpectedly high amount (KU 13p; Pl. 3, Fig. 1), just as in the Yubari dome (Yb 427b in OKada et al. in Matsumoto and Harada, 1964).

Relations between garnet and other associated minerals are discussed in page 100 .

(4) Epidote. Epidote occurs in general as irregular and subangular grains and sometimes as prismatic ones. It is interesting that epidote is much more abundant on the eastern wing of the anticline and on the western wing than on the southwestern wing.

Epidote is one of the index minerals of the Mikasa Formation, as FuJII (1958) has already pointed out.

(5) Augite. Augite occurs as pale green, prismatic grains, which present fresh character. Not a few grains exhibit a hack-saw structure.

Augite and epidote characterize the Mikasa Formation (Fig. 16 and Table 5). This is also true in the Yubari dome (OKADA et al. in Matsumoto and Harada, 1964).

(6) Hypersthene. The occurrence of hypersthene is sporadic. Most of the grains are prismatic and much larger than the average size of other heavy minerals.

(7) Hornblende. Hornblende is low in frequency, but persistently occurs in all the specimens. Most of the grains are greenish-brown in colour, and a small fraction of them are green. Each grain is prismatic euhedron.

(8) Tourmaline. Three varieties of tourmaline are distinguished on the basis of colour; brown, green-shaded and blue. The blue variety is not common. Many of the euhedral tourmaline crystals are broken at one or both edges. Some are rounded.

(9) Rutile. More or less rounded prismatic or acicular grains are met with.

(10) Apatite. It occurs as short prismatic euhedron with bipyramidal termination or with basal pinacoid. Indeterminable acicular inclusions are common in parallel with the principal axis.

Specially noteworthy is the fact that apatite is very abundant in a tuffaceous sandstone (Sp. No. IK 1056e; see Fig. 16 and Table 4), although it is traceable in ordinary sandstones. The acicular apatite indicative of a particular genetic condition (WylliE et al., 1962) is not detected.

(11) "Chromite". The so-called chromite is sporadically met with. The grains are massive and irregular, showing conchoidal fracture. Marginal edge of a fragment presents a colour of reddish brown to deep blood-red. Judging from these features it may be either magnesiochromite or chromian spinel.

(12) Anatase. Anatase occurs as golden yellow, tabular grains with zoning. Since no abrasion is recognized on the grain, anatase is considered to be of authigenic origin. Its occurrence seems to be confined to coarse-grained sandstones, as has been reported by FujII (1956).

(13) Mica group. Biotite and muscovite or sericite are present throughout the formation, although their amout is variable from sample to sample. Their frequency may not be evaluated in the same way as that of other associated minerals, because 
they may be to a considerable extent lost during the course of separation. Muscovite or sericite, making up a part of clay matrix, is composed of aggregates of fibers. Biotite consists of brown, reddish brown and greenish varieties. Usually it shows fibrous, prismatic, or irregular platy characters, and sometimes it occurs as a hexagonal plate. Its partial alteration to chlorite is also observed.

(14) Iron minerals. Pyrite, marcasite, magnetite, ilmenite, hematite and leucoxene are distinguished. Their qualitative amount is shown on Tables 4 and 5 .

Table 7. X-ray diffraction data of pyrite and ilmenite.

\begin{tabular}{|c|c|c|c|c|c|c|}
\hline \multicolumn{3}{|c|}{ Pyrite (Sp. No. KU 227) } & \multicolumn{4}{|c|}{ Ilmenite (Sp. No. IK 1056e) } \\
\hline I & $d(\AA)$ & $h k l$ & I & $d(\AA)$ & hkil & $h k l$ \\
\hline 3 & 3. 13 & 111 & 2 & 3.72 & 0112 & 110 \\
\hline 10 & 2.71 & 002 & 10 & 2.75 & 1014 & 211 \\
\hline 7 & 2. 42 & 021 & 3 & 2.54 & $11 \overline{2} 0$ & $10 \overline{\mathrm{I}}$ \\
\hline 6 & 2.21 & 112 & 2 & 2.23 & $11 \overline{2} 3$ & 210 \\
\hline 5 & 1.917 & 022 & 2 & 1.865 & $02 \overline{2} 4$ & 220 \\
\hline 1 & 1.803 & 122 & 4 & 1.723 & $11 \overline{2} 6$ & 321 \\
\hline 8 & 1. 634 & 113 & 1 & 1. 629 & $\{0118$ & 332 \\
\hline $1 \frac{1}{2}$ & 1.565 & 222 & & & 10232 & $22 \mathrm{i}$ \\
\hline 2 & 1.504 & 023 & $1_{2}^{\frac{1}{2}}$ & 1.505 & $21 \overline{3} 4$ & 310 \\
\hline 3 & 1.446 & 123 & $1 \frac{1}{2}$ & 1.468 & $30 \overline{3} 0$ & $2 \overline{\mathrm{I}} \overline{\mathrm{I}}$ \\
\hline
\end{tabular}

Notes : 1) FeK $\alpha$; Scan. speed $2^{\circ} / \mathrm{min}$; Time const. 2.5 secs.; Slits $3-2-0.6 \mathrm{~mm}$.

2) $h k l$ and $h k i l$ are cited from BERRY and THOMPson (1962).

Of these iron minerals, pyrite is most abundant, which is identified with an $\mathrm{X}$-ray analysis (Table 7). It occurs as spherule or spheroid, striated pyritohedra, isometrics and clusters of globules. Moreover, spherular pyrite almost always replacing radiolarian or probably other spheric microfossil remains is confined in occurrence to the lower part of the Middle Yezo Group and is particularly common in the Yunosawa Sandstone, whereas in the Mikasa Formation spherular one is very rare, but pyritohedral or isometric pyrite is common. Similar occurrence of pyrite is also observed in the Cretaceous succession in the Yubari dome, where spherular pyrite replacing microfossils occurs in Member $\mathrm{L}_{1}$ [of $\mathrm{K}_{\beta}$ age] of the Middle Yezo Group (MAtsumoto and Harada, 1964) (Pl. 6, Fig. 3), but does not occur in the overlying Mikasa Formation (MATSUmoTo and HARADA, 1964). In addition, authigenic marcasite presenting radial texture as reported by OKADA (1960a) is detected only in a specimen KU 32 of the lower part of the Middle Yezo Group (Table 3).

Such an interesting occurrence of a certain type of iron sulphides may suggest a special sedimentary environment which will be a subject of further study.

As a special case ilmenite exclusively makes up the bulk of heavy minerals of a tuffaceous sandstone [Sp. No. IK 1056e] (Tables 4 and 7; Pl. 4, Fig. 2). 


\section{E. A few comments on heavy minerals}

\section{Index minerals of the Mikasa Formation and heavy mineral suites}

Heavy mineral analysis reveals that a combination of garnet and zircon and that of epidote and augite which are altogether more than 80 percent of the whole nonopaque heavy minerals are very significant as indices of the Mikasa Formation. Especially, the garnet-zircon suite is characteristic of the southwestern wing of the anticlinal area, and the combined suite of the garnet-zircon and the epidote-augite characterizes both the eastern and the western wings.

From the standpoint of source rocks, the heavy mineral assemblages are grouped into the following five suites:

1) Euhedral zircon-garnet-green hornblende-green and blue tourmaline-rutile-biotiteiron minerals........ acid igneous origin

2) Epidote-augite-hypersthene-brown hornblende-(apatite)-iron minerals........intermediate to basic igneous origin

3) "Chromite"-iron minerals.......ultrabasic origin

4) Rounded zircon-rounded garnet-rounded rutile tourmaline........sedimentary origin

5) Anatase-spherular pyrite-marcasite-leucoxene........authigenic origin

Of the above suites, the first, second and fourth ones, i.e. those of acid to basic igneous origin and of sedimentary one are predominant.

\section{Behaviour of heavy mineral grains}

It is very difficult to extract quantitatively from coagulated sediments factors controlling the behaviour of mineral grains in the process of transportation and sedimentation. In this respect, researches of recent sediments give us useful information for better understanding of sediments of old ages. BURRI (1929), PETTIJoHN and Ridge (1933), Rittenhouse (1943), Van ANDEL (1954), etc. studied heavy mineral behaviours in recent sediments and clarified many interesting facts. Summarizing the results of these previous works, important factors controlling a mineral assemblage are the texture and mineral composition of source rocks, nature of transportation media, velocity of the media, distance of transportation, bottom condition of a basin of deposition and specific gravity, size and shape of mineral grains.

In this study, a few interesting facts have been observed on behaviours of zircon, garnet, epidote and augite. The amount of zircon and garnet increases with decreasing content of epidote and/or augite (Figs. 13 and 14 ; Pls. 3-6). There is a linear relation between zircon and garnet and also between epidote and augite (Figs. 12 and 15). In general, concentration of mineral in sediments is intensely influenced with its grain size (RitTenhouse, 1943 ; Van ANDEL, 1955). In the studied area, zircon and garnet are, on one hand, obviously concentrated in the coarse-grained facies on the western and the southwestern wings of the anticline, and on the other, epidote and augite are characteristic of the fine-grained facies on the eastern wing and in the northern part of the western wing (P1. 4, Figs. 1-4, 5; Pl. 5, Figs. 2-6; Pl. 6, Figs. 1, 2). In this connection, garnet tends to gather in far the coarser fraction and therefore in the coastal areas (HAwkEs et al., 1931; TAKAHASHI et al., 1950; MCMASTER, 1962). On 
the other hand, augite assembles in finer fraction, according to Kondo's study of recent coastal sediments (Kondo, 1960).

In addition to the grain size, the specific gravity of a mineral seems to be significant for controlling the distribution of a mineral under the influence of the winnowing by current. Zircon and garnet have similarly high specific gravity to behave in common with each other, as do epidote and augite.

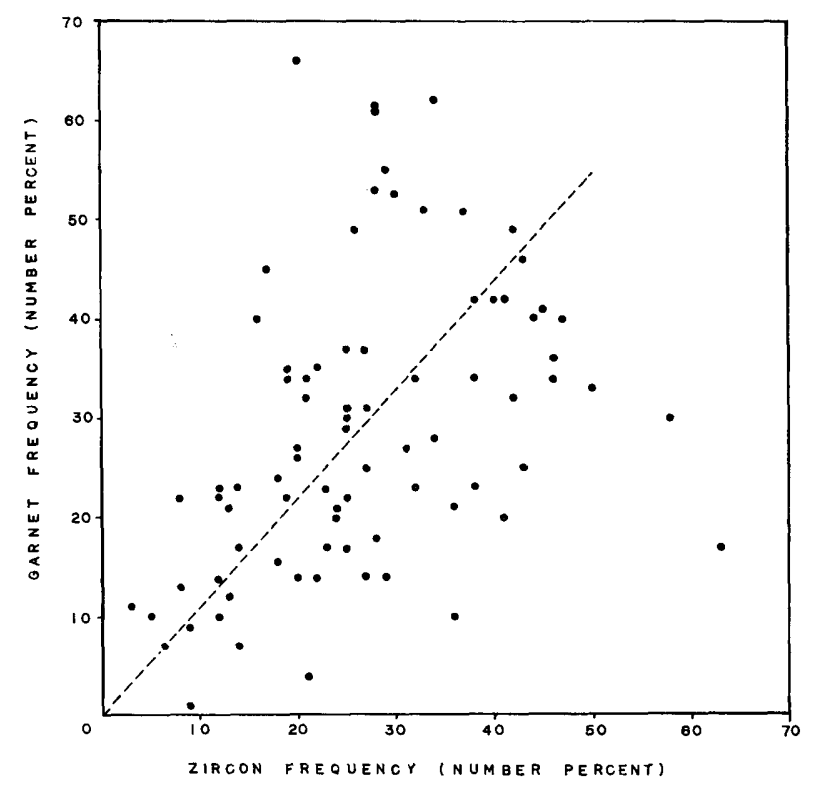

Fig. 12. Relation between the frequencies of zircon and garnet.

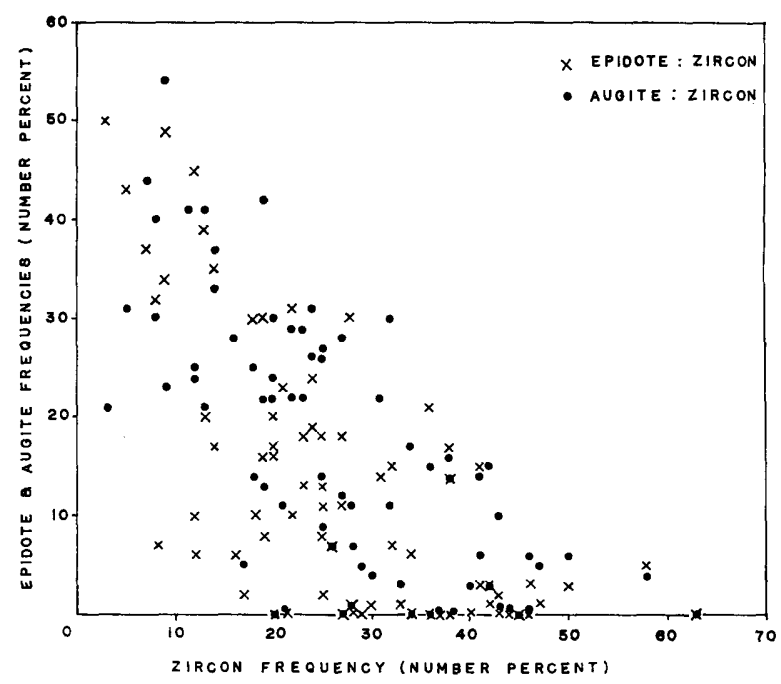

Fig. 13. Relations between the frequencies of zircon and epidote and between those of zircon and augite. 
In this respect, PetTIJohn and RIDGE (1933) have reported in their study of beach sand at Cedar Point, Lake Erie, Ontario, that in the direction of transport garnet declines notably; hornblende increases complementarily ; and diopside and hypersthene are almost constant in frequency.

Likewise a sort of progressive sorting-action is considered to have caused the above mentioned characteristic distribution of particular minerals in the Mikasa Formation.

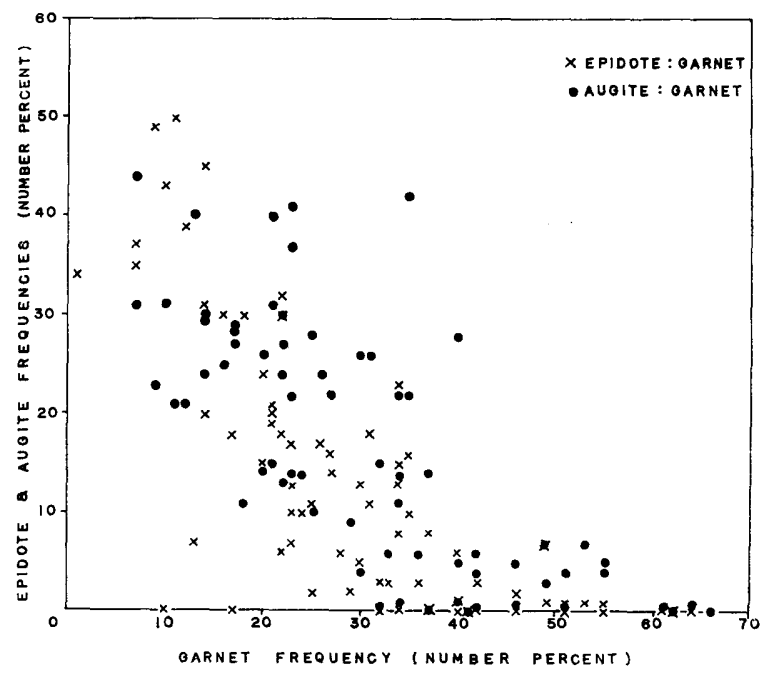

Fig. 14. Relations between the frequencies of garnet and epidote and between those of garnet and augite.

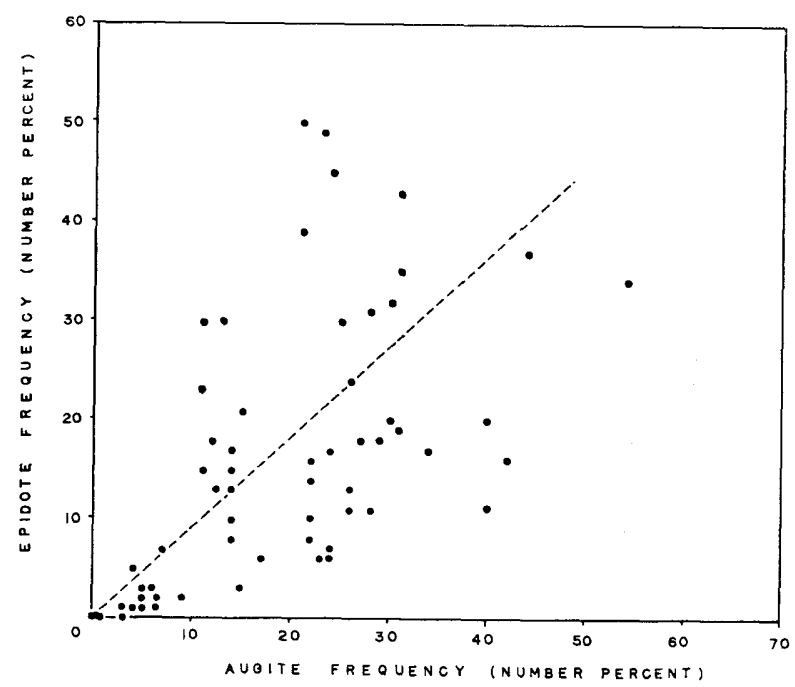

Fig. 15. Relation between the frequencies of epidote and augite. 


\section{F. A note on the sandstones of the Cretaceous section along the Ikushumbets Valley}

The Cretaceous section along the Ikushumbets Valley is very important in that a standard stratigraphy of the Middle and Upper Yezo Groups has been established there (MAtsumoto, 1959; see Fig. 5). Therefore, it is desirable to give some petrologic comments on the sandstones of each stratigraphic unit. Stratigraphic division used in this paper follows that of Matsumoto (1959) and Matsumoto et al. (1960).

1. Lower part of the Middle Yezo Group $[I]$

a. The Yunosawa Sandstone

Thirteen specimens of the Yunosawa Sandstone (FUKADA et al., 1953) have been examined (Tables 2 and 4). All are more or less calcareous and fall in the subgraywacke clan. However, the roundness of detrital grains is not so good. Of major constituents quartz is for the most part of igneous origin. Rock fragments consist mainly of andesitic rocks and sandy to silty sedimentaries. Heavy mineral assemblages are overwhelmed by zircon and garnet of almost equal amount, being accompanied with a small amount of tourmaline (Fig. 16; Pl. 3, Figs. 2-5). As an interesting fact, the spherular authigenic pyrite described in page 99 is characteristic of the whole Yunosawa Sandstone, especially of the alternating part, the lower horizon of the Yunosawa. It is likewise noteworthy that a specimen KU 32 is characterized by an authigenic marcasite (Table 4 ; Fig. 16).

b. The Sequence above the Yunosawa Sandstone

The sandstone of this sequence is different from the preceding one in that it bears a considerable amount of clay matrix (Table 2). Consequently it is for the most part graywacke. Heavy mineral assemblages of the sandstone, however, do not basically deviate from those of the underlying sequence, except for the forerunning appearance of augite and epidote (Fig. 16; P1.3, Fig. 6). Spherular authigenic pyrite is sporadically met with.

2. Mikasa Formation [II]

a. Basal and Lower Members [II a and IIb]

In this sequence the sandstone is clearly distinguishable from that of the underlying sequence $I$. The sandstone is graywacke and is always considerably muddy (Fig. 17; Table 2). Further remarkable feature is that augite and epidote get suddenly significant besides zircon and garnet (Fig. 16; P1. 4, Figs. 1, 3, 4).

A bed represented by a specimen IK $1056 \mathrm{e}$ at the base of Member IIa is tuffaceous sandstone rich in volcanic rock fragments (andesitic). This sandstone abounds in ilmenite, which occupies about 90 percent of heavy minerals, and is also characterized by apatite as a transparant heavy mineral (Pl. 4, Fig. 2).

b. Middle Member $[I I c]$

As this unit is wholly made up of siltstone, there is no sandstone to be described here.

c. Upper Member [IId]

Characters of the sandstone are exactly the same as those of Members IIa and 


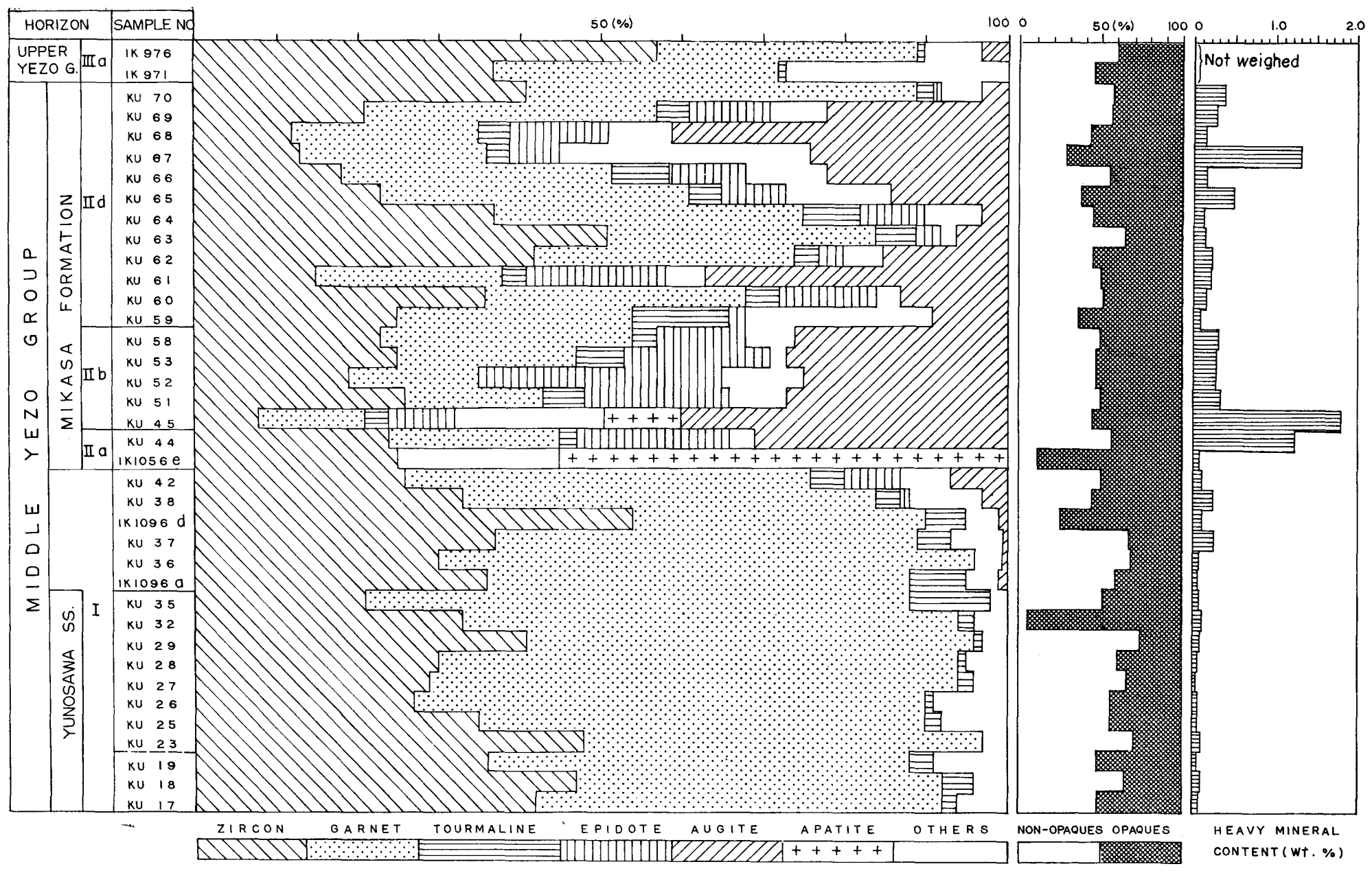

Fig. 16. Vertical change of non-opaque heavy mineral compositions of the sandstones in the standard stratigraphic section along the Ikushumbets Valley [XII] (on the eastern wing) (see also Fig. 5). 
IIb (Table 2; Pl. 1, Fig. 2). Some of the sandstones are considerably calcareous. Some specimens contain a dominantiamount of zircon and garnet, but these minerals are always accompanied to a certain extent by augite and epidote.

3. Upper Yezo Group $[I I I]$

The Upper Yezo Group is mainly composed of siltstone, with some intercalated beds of sandstone and tuff. So far as the examined specimens are concerned, a specimen IK 971 belongs to the graywacke, and the other two, IK 1121 and IK 1263 are tuffaceous sandstones which are remarkably predominated by andesine plagioclase (Pl. 1, Fig. 3).

According to the available specimens and the results of FuJII's study (1958), heavy mineral composition of the Upper Yezo Group is rather similar to that of the sequence above the Yunosawa Sandstone (Pl. 4, Fig. 5).

The above mentioned features of the sandstone are precisely exhibited in Fig. 16 and 17.

These characters of the sandstone of each stratigraphic unit are very similar to

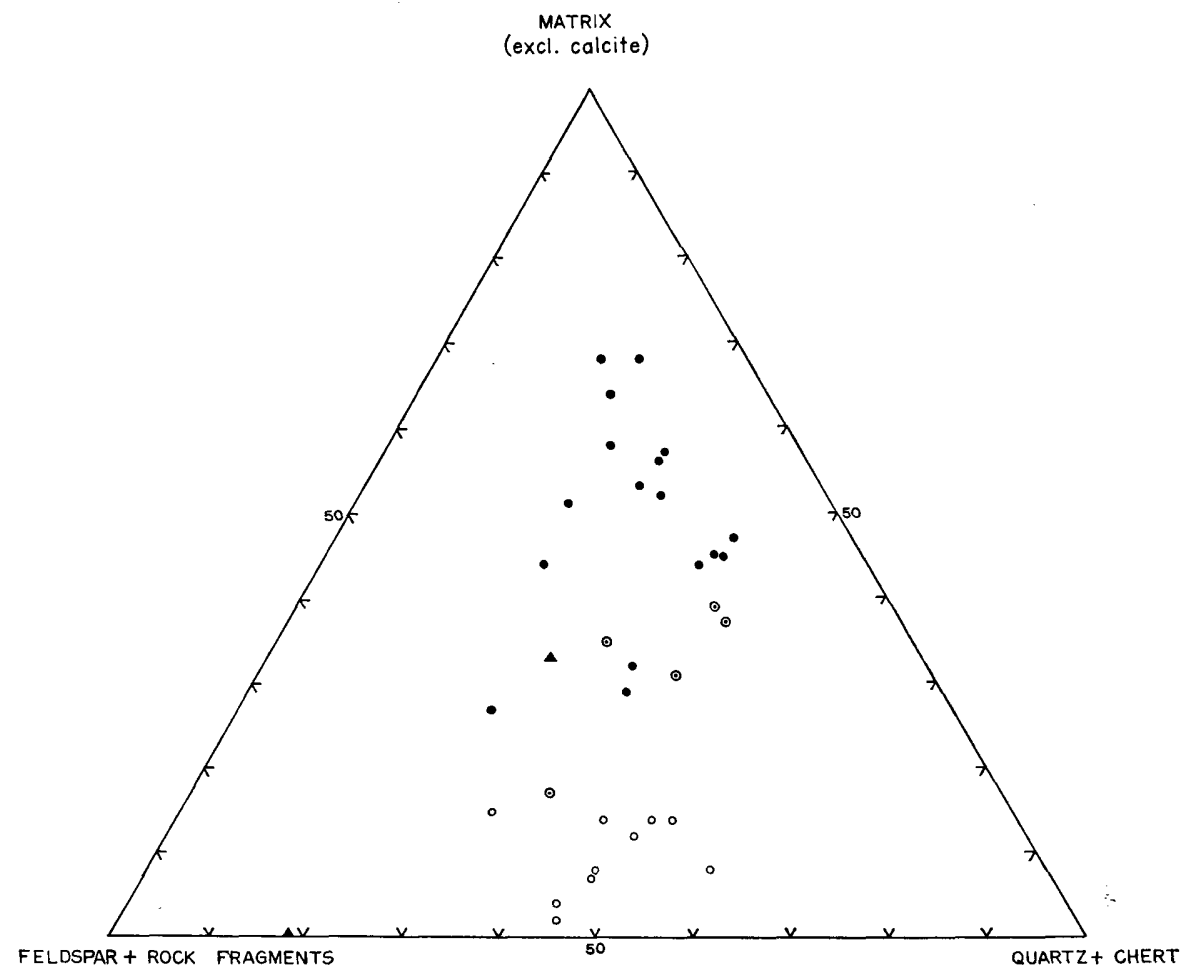

Fig. 17. Diagram showing compositional difference of the sandstones of the Mikasa Formation and its overlying and underlying sequences in the Ikushumbets Valley [XII] (eastern wing).

-Yunosawa Sandstone.

- - Sequence above the Yunosawa Sandstone.

-Mikasa Formation.

A-Upper Yezo Group. 
those of the sandstone of the corresponding stratigraphic sequence in the Yubari dome (Okada et al. in Matsumoto and Harada, 1964) (Pl. 6, Figs. 3-6).

\section{G. A note on the Lower Tertiary sandstones}

In the Ishikari coal field it has been already pointed out by IMAI (1924) and many other authors that the Cretaceous System is ovarlain by the Palaeogene Ishikari Group with parallel unconformity. Certain parts of the Cretaceous sediments, for instance, the Hakobuchi Group of a regressive facies, are said in some places to be hardly descriminated from the Lower Tertiary because of their lithologic similarity (TAKAO, 1952).

In the Ikushumbets anticlinal area the Cretaceous is also overlain by the Palaeogene with a parallel unconformity (IMAI, 1924; YABE, 1927; TASHIRO, 1951; TAKAO, 1952 ; Matsumoto [Editor], 1954, etc.). In particular, the Mikasa Formation on the western wing is in contact with the Palaeogene Ikushumbets coal-bearing Formation, both of which are apparently similar in aspects to each other.

Several petrological studies have been undertaken for the Lower Tertiary. Recently IIJIMA has analysed heavy minerals of them (IIJIMA, 1957, 1959). I myself also attempted a petrologic study (OKADA, 1960a). From these and other petrographic and mineralogic studies (OTATUME et al., 1939; TAKAO, 1952; IKEGAMI, 1958, 1959, 1960, etc.), the petrologic distinction of the Ikushumbets Formation from the Mikasa Formation may be described in the following.

1. Sandstones of the Ikushumbets Formation

The Ikushumbets sandstone, which is fine- to medium-grained and sometimes conglomeratic, is yellowish gray $(5 Y$ 8/1) to light gray (N7) in colour, being usually scattered with small brownish spots and sometimes stained with brownish laminae. The sandstones consist mainly of quartz, chert, andesitic rock fragments and feldspars as detritus and are more or less calcareous. They are divided into two rock types, subgraywacke and graywacke, of which the former is predominant. The feldspar content throughout the whole sandstone is at most 16 percent.

A characteristic feature of the Ikushumbets sandstone is the carbonate cement of a considerable amount, which comprises calcite and siderite (ОKADA, 1960a). Siderite occurs generally either as brownish spots of irregular shape (aggregates of microcrystallines) or as laminae. The siderite in the Lower Tertiary sediments of the Ishikari coal field was first noticed by Otatume and Fukushima (1939), and its study was extended by IKEgAMI $(1958,1959,1963)$ and OKADA (1960a). According to IKEGAMI (1959), it sometimes occurs as nodules of various sizes in the sandstone and also in the shale of the Ikushumbets Formation.

In addition to the above, other minerals typical of the Ikushumbets sandstone are some sulphides such as pyrite and marcasite, both of which occur in very high frequency. Marcasite presents a peculiar outline of stellate form (OKADA, 1960a, Pl. 11, Fig. 7). Of the transparent heavy minerals, zircon, garnet and tourmaline are important, being accompanied with anatase. Rarely glaucophane is met with.

For more details of the heavy mineral assemblages of the Ikushumbets saddstone, 
readers may refer to IIJIMA $(1957,1959)$ and OKADA (1960a).

2. Comparison between the Ikushumbets and the Mikasa sandstones

Sandstones of the Ikushumbets and the Mikasa Formations on the western and the southwestern wings, where they are in contact, are both characterized by subgraywackes. Therefore, sandstone composition in terms of major constituents is very similar to each other (Fig. 18). The Ikushumbets sandstone, however, is distinguished from the Mikasa in the presence of siderite, which is also known throughout the non-marine Lower Tertiary in the Yubari area, such as the Noborikawa (TAKAO, 1952 and preliminary observation of myself), the Horokabets (IKEGAMI, 1963) and the Yubari Formations (IKEGAMI, 1963 and preliminary observation of myself).

Furthermore, the Ikushumbets and the Mikasa sandstones are respectively characterized by the dissimilar heavy mineral suites as follows:

1) The Ikushumbets sandstone: zircon-garnet-tourmaline-marcasite-pyrite-anatase

2) The Mikasa sandstone: garnet-zircon-epidote-augite

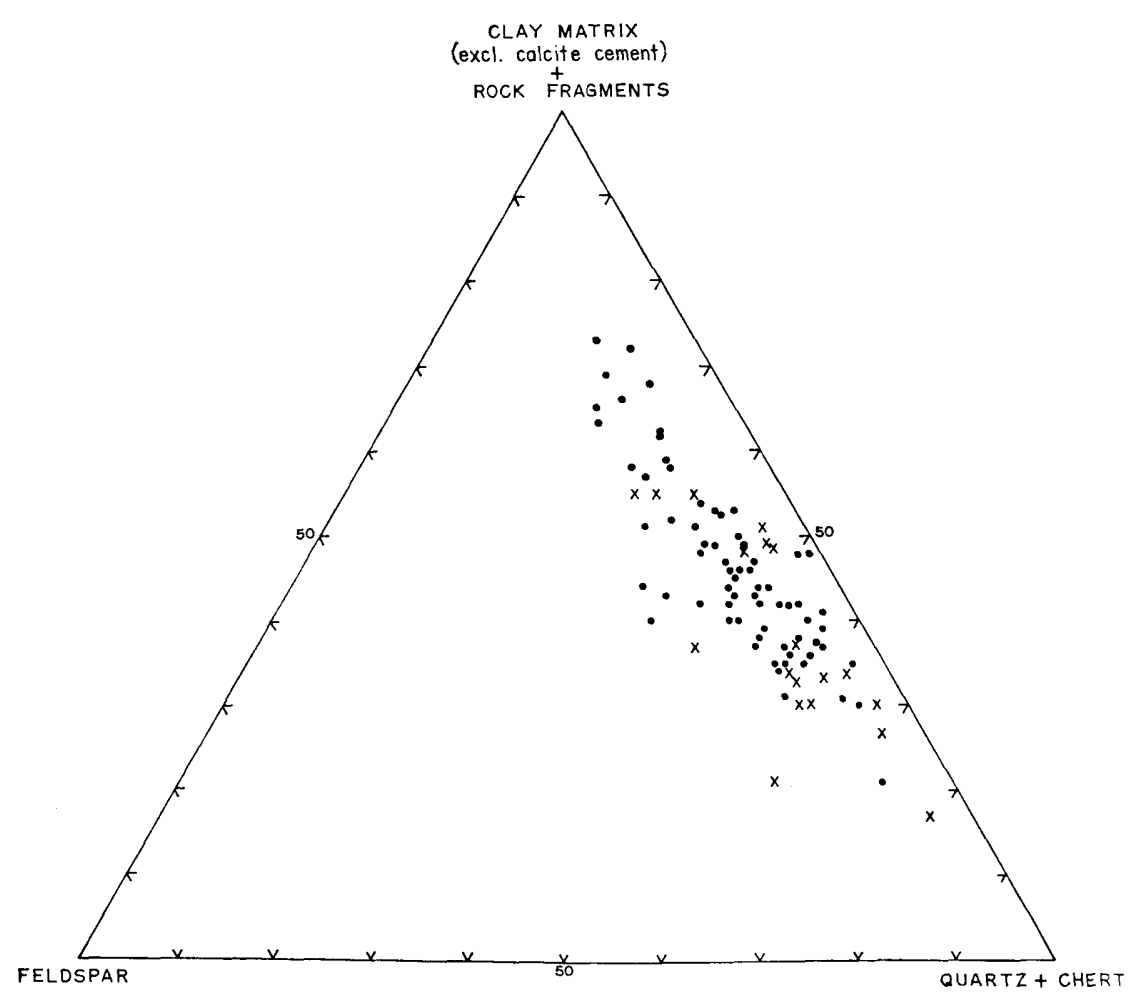

Fig. 18. Comparison in major mineral composition between the sandstones of the Middle Yezo Group and those of the Palaeogene Ikushumbets Formation.

- Middle Yezo Group.

X-Ikushumbets Formation (OKADA, 1960a). 


\section{Concluding Remarks}

On the grounds of the described facts I discuss in this chapter about the source rocks and sedimentary environments of the Mikasa Formation.

1. Source rocks

Possible framework of source rocks of the Mikasa sandstone is summarized as follows from the major components and heavy mineral associations, as well as kinds of pebbles and cobbles:

Older sedimentary rocks: cherts with and without radiolarians, graywacke, slate and acid to intermediate tuff

Acid igneous rocks: granitic rocks (bearing microcline) and aplite

Intermediate to basic igneous rocks: andesite, porphyrite and diabase

Ultrabasic rocks

Besides, FUJII (1958), in this petrographic study of the Cretaceous sandstones, postulated low-grade metamorphic rocks as one of the Mikasa Formation.

Of these, the most predominant is older sedimentaries and others are subordinate. Especially, in relation to the basic to ultrabasic source rocks, the presence of chromian spinel or magnesiochromite is significant, since it has not been reported from the Yezo Group except for my preliminary study (OKADA, 1962). The mineral is, however, so little in amount that its transportational direction is hardly determined.

General palaeogeographic accounts of the provenance of the detritus of the Mikasa Formation are discussed in the following.

\section{Sedimentary environments}

To begin with, it seems to be relevant for the discussion to summarize sedimentologically analysed features of the Mikasa Formation.

(A) Megafacies

(a) Thickness

(b) Change of lithofacies

(c) Conglomeratic parts

(d) Sandstone pattern

(e) Coarse clastics/silt ratio

(f) Coaly layers

(g) Redbeds

(h) Sedimentary structure

(i) Ostrea

(j) Trigonia

(k) Ammonites
Western wing

180-270 m
moderate
common
graywacke
subgraywacke
$8-19$
$3-4$ (each less than
20 cm thick) at the
upper horizons
present
ripple marks and
cross-lamination
common

common in limited beds

generally rare, occurring in limited beds

\begin{tabular}{|c|c|}
\hline $\begin{array}{l}\text { Southwestern } \\
\text { wing }\end{array}$ & Eastern wing \\
\hline $\begin{array}{l}110-240 \mathrm{~m} \\
\text { great }\end{array}$ & $\begin{array}{l}240-405 \mathrm{~m} \\
\text { little }\end{array}$ \\
\hline predominant & poor \\
\hline subgraywacke & graywacke \\
\hline $62-120$ & $1.5-6$ \\
\hline not yet found & absent \\
\hline $\begin{array}{l}\text { not yet recognized } \\
\text { ditto }\end{array}$ & $\begin{array}{l}\text { absent } \\
\text { not common }\end{array}$ \\
\hline common & $\begin{array}{l}\text { absent or only } \\
\text { fragmental if } \\
\text { present }\end{array}$ \\
\hline $\begin{array}{l}\text { common in limited } \\
\text { beds }\end{array}$ & not common \\
\hline very rare & $\begin{array}{l}\text { common, except in } \\
\text { IId }\end{array}$ \\
\hline
\end{tabular}


(1) Other marine shells moderate in
particular beds

(B) Microfacies (especially of sandstones)

(m) Sorting

(n) Grain-size distribution

(o) Roundness

(p) Maturity

(q) Heavy mineral suites

$\begin{array}{ll}\text { moderate } & \text { good } \\ \text { sometimes unimodal } & \text { unimodal } \\ \text { C-D (fairly well- } & \text { C-D } \\ \text { rounded); rarely B } & \\ \begin{array}{l}\text { moderate } \\ \text { garnet-zircon-epidote- } \\ \text { augite }\end{array} & \text { gigh } \\ \end{array}$

common

poor

polymodal

B (subangular); rarely $\mathrm{C}$

low

epidote-augite-garnetzircon

As is easily understood from the above facts, the Mikasa Formation on the eastern wing in general represents comparatively offshore sediments, that on the western wing sediments of shallower facies than those on the eastern, and that on the southwestern wing the beach-like deposits under strong current-agitation, the last of which may mean a marigin of the depositional basin.

As an outline of the palaeogeographic framework, therefore, a mountainous land must have been generally on the west side of the basin. The main provenance of the detritus of the Mikasa Formation was certainly in this land. This conclusion generally conforms to what Matsumoto (1943, p. 184-5) had outlined from his stratigraphical study. The shoreline was not necessarily parallel to the trend of the folding. It may have been rather oblique to the latter, running roughly north to south or NNW-SSW, and may have had some irregularity. The site of the southwestern wing of the Ikushumbets anticline may have been incidentally very close to the seashore. Throughout the period of sedimentation of the whole Yezo Group, the emergence of the western uplift proceeded more intensely during the Gyliakian stage than in any other stages of the Group and most strongly so in the middle part of Upper Gyliakian (middle Turonian).

In connection with the above conclusion it is noted that sediments of the Middle Yezo Group narrowly exposed on the north side of the Pombets fault (Figs. 2-4) is similar in both lithology and composition to the Mikasa Formation on the western wing of the Ikushumbets anticline (see Table 5 and Fig. 1 on Plate 5 as regards the heavy mineral assemblages). Hence, there seems to have been at that time on uplift along the Pombets fault on a scale significant enough to control the nature of sediments, although TANAKA (1959) assumed the existance of such an up-warping belt.

3. Volcanism

Volcanic activity during the period of sedimentation slightly influenced the sediment in this area, as is suggested from the intercalation of acid to intermediate tuff, tuffite and tuffaceous sandstone in a few limited places.

\section{References Cited}

Berry, L. G. and Thompson, R. M. (1962) : X-ray powder data for ore minerals. The Peacock Atlas. Geol. Soc. Am. Mem. 85, 1-281.

BurRi, Conrad (1929): Sedimentpetrographische Untersuchungen an alpinen Flussanden. Schweiz. minerlog. Petrog. Mitt., 9, 205-240.

Folk, R.L. (1951): Stages of textural maturity in sedimentary rocks. Jour. Sediment. Petrol., 
21, (3), 127-130.

Fujr, Koji (1956): Sandstones of the Mesozoic formations in the Yatsushiro district, Kumamoto Prefecture, Kyushu, Japan (in Japanese with English abstract). Jour. Geol. Soc. Japan, 62, (727), 193-211.

(1958): Petrography of the Cretaceous sandstones of Hokkaido, Japan. Mem. Fac. Sci., Kyushu Univ., Ser. D, Geol., 6, (3), 129-152, pl. 23.

Fukada, Atsuo, Ishin, Jiro, Ichikawa, Teruo and Saraki, Masao (1953): Cretaceous system along the Ikushumbets Valley (in Japanese). Hokkaido Chishitsu Yoho [Periodical of the Geological Society of Hokkaido], 23, 1-19.

Goddard, E.N. [Chairman] (1951): Rock color chart. 2nd print. Geol. Soc. Am., New York.

Hawkes, L. and Smythe, J.A. (1931): Garnet-bearing sands of the Northumberland Coast. Geol. Mag., 68, (8), 345-361.

IIJima, Azuma (1957): Preliminary note on the heavy mineral association of the Ishikari series (Eocene-Oligocene) in the Ishikari, Kabato and Rumoi coal fields in Hokkaido, Japan. Jour. Geol. Soc. Japan. 63, (737), 67-81, pl. 3.

(1959): On relationship between the provenances and the depositional basins, considered from the heavy mineral associations of the Upper Cretaceous and Tertiary formations in central and southeastern Hokkaido, Japan. Jour. Fac. Sci., Univ. Tokyo, Sec. II, 11, (4), 339-385, pls. 21-23.

IKEGAmi, Sigeo (1958): Prelimary note on the sideritic band (iron stone) in the Horokabetsu Formation in the Ishikari coal field (in Japanese). Jour. Min. Soc. Japan, 3, (6), 592-596. (1960): Note on the sideritic band (iron stone) in the Ikushumbetsu, Ponbetsu district in the Ishikari coal field (Mikasa City, Hokkaido) (in Japanese). Jour. Hokkaido Gakugei Univ., Sec. IIB. 11, (1-2), 159-168, pls. 1-5.

(1963): On the sideritic rocks in coal fields of Hokkaido, Japan (in Japanese). Ibid., 13, (2), 259-285, pls. $1-4$.

(1963) : Ditto. Part II. (in Japanese). Ibid., 14, (1), 75-90.

Kondo, Seizo (1960): Beach iron placer in the Choshi Peninsula (in Japanese). Res. Rept. Choshi Marine Labor., Chiba Univ., (2), 32-35.

McMaster, Robert L. (1962): Petrography and genesis of recent sediments in Narragansett Bay, Rhode Island Sound, Rhode Island. Jour. Sediment. Petrol., 32, (3), 484-501.

Matsumoto, Tatsuro (1942-43): Fundamentals in the Cretaceous stratigraphy of Japan. Part I. Mem. Fac. Sci., Kyushu Univ., Ser. D, Geol., 1, (3), 129-280; Parts II and III. Ibid., 2, (1), 97-237.

(1951): The Yezo Group and the Kwanmon Group (in Japanese with English abstract). Jour. Geol. Soc. Japan, 57, (666), 95-98.

- [Editor] (1954): The Cretaceous System in the Japanese islands. i-xiv, 1-324, pls. 1-20, Japan. Soc. Prom. Sci. Res., Tokyo.

(1959): Zonation of the Upper Cretaceous in Japan. Mem. Fac. Sci., Kyushu Univ., Ser. D, Geol., 9, (2), 55-93, pls. 6-11.

Matsumoto, Tatsuro, Muramoto Tatsuo, Muramoto, Kikuo and Kikuchi, Masanobu (1960): Biostratigraphy of the Cretaceous System in Ikushumbets, Hokkaido (Abstract) (in Japanese). Jour. Geol. Soc. Japan. 66, (778), 465.

Matsumoto, Tatsuro, Okada, Hakuyu, Orita, Yukinobu and KanNo, Saburo (1963): Serpentine sandstone (in Japanese). Ibid., 69, (812), 239-241.

Matsumoto, Tatsuro and Harada, Masato (1964): Cretaceous stratigraphy of the Yubari dome, Hokkaido; with an appendix: "Petrographic notes on the Cretaceous sandstones of the Yubari dome" by H. Okada, M. Harada and T. Matsumoto. Mem. Fac. Sci., Kyushu Univ., Ser. D, Geol., 15, (1), 79-115, pls. 9-11.

OKadA, Hakuyu (1960a): Sandstones of the Palaeogene Ikushumbetsu coal-bearing formation, Hokkaido, Japan. Japan. Jour. Geol. Geogr., 31, (2-4), 149-164, pl. 11. - (1960b): Sandstones of the Cretaceous Mifuné Group, Kyushu, Japan. Mem. Fac. Sci., Kyushu Univ., Ser. D, Geol., 10, (1), 1-40, pls. 1-5.

(1961): Trigonia Sandstone of the Sorachi anticlinal area, Hokkaido (abstract) (in 
Japanese). Jour. Geol. Soc. Japan, 67, (790), 403.

- (1962): The Cretaceous sandstones in the Teshio and Kitami areas, Hokkaido (Abstract) (in Japanese). Ibid., 68, (802), 416.

- (1963): The Cretaceous sandstones in the Tomiuchi area, Hokkaido (Abstract) (in Japanese). Ibid, 69, (814), 336.

(1964): Serpentine sandstone from Hokkaido. Mem. Fac. Sci., Kyushu Univ., Ser. D, Geol., 15, (1), 23-38, pls. 4-5.

Otatume, Ken-itiro (1940-41): On the overthrust-sheets in the southern part of the Ishikari coal-field, Hokkaido (in Japanese with English abstract). Jubilee Publication in the Commen. of Professor H. YAl3E's Sixtieth Birthday, 2, 973-988.

Otatume, Ken-itiro and Fukushima, Tokio (1939): On the rocks of each formation of the Ishikari Series (Abstract) (in Japanese). Jour. Geol. Soc. Japan, 46, (549), 311-312.

Pertijohn, F.J. (1957): Sedimentary rocks, 2nd Ed. i-xvi, 1-718, Harper \& Brothers, N.Y.

Pettijohn, F.J. and Ridge, J.D. (1933): A mineral variation series of beach sands from Cedar Point, Ohio. Jour. Sediment. Petrol., 3, 92-94.

Rittenilouse, Gordon (1943) : Transportation and deposition of heavy minerals. Geol. Soc. Am. Bull., 54, (12), 1725-1780.

SRIRAMADAS, A. (1957): Diagrams for the correlation of unit cell edges and refractive indices with chemical composition of garnets. Am. Min., 42, (3-4), 294-298.

TAkAhashi, Jun-ichi and KitAhara, Jun-ichi (1950): Studies on garnet and augite placer deposits at Wa-Are, South Sakhalin (in Japanese with English abstract). [1]. Jour. Japan. Petrol. Mineral. Econ. Geol., 34, (5), 165-172; [2]. Ibid., 199-204.

TAKAO, Shohei (1952): Study of the stratigraphy and geological structure of the Poronai Formation in the Ishikari coal field, especially in the Yubari coal field (in Japanese). Studies on Coal Geology, No. 2, Hokkaido Assoc. Coal Mining Technologists, 1-216.

TANAKA, Keisaku (1959): On the sedimentation of the Cretaceous deposits, especially of the Upper Yezo Group in the Sorachi anticlinal area, Ishikari coal field (in Japanese with English abstract). Bull. Geol. Surv. Japan, 10, (12), 27(1063)-41(1077).

(1963): A study on the Cretaceous sedimentation in Hokkaido, Japan. Rept. Geol. Surv. Japan, (197), 1-119, pls. 1-3.

TASHIRo, Shuichi (1951): A consideration on the geological structure of the Ishikari coal field in Hokkaido (in Japanese). Studies on Coal Geology, No. 1, Hokkaido Assoc. Coal Mining Technologists, 1-64.

Van Andel, Tj.H. (1955): Sediments of the Rhone delta. II. Sources and deposition of heavy minerals. Geol. Mijnbouwk. Gen. Neder. Verh., 15, (3), 516-556,

Wyllie, P.J., CoX, K.G. and Bigger, G.M. (1962): The habit of apatite in synthetic systems and igneous rocks. Jour. Petrol., 3, pt. 2, 238-243.

YABE, Hisakatsu (1903): Cretaceous Cephalopoda from the Hokkaido. Part I. Lytoceras, Gaudryceras and Tetragonites. Jour. Coll. Sci., Imp. Univ. Tokyo, 18, (2), 1-55, pls. 1-7. (1909): Zur Stratigraphie und Paläontologie der oberen Kreide von Hokkaido und Sachalin. Zeitsch. d. deutsch. Geol. Gesellsch., 61, 402-444.

(1926 a): A new scheme of the stratiraphical subdivision of the Cretaceous deposits of Hokkaido. Proc. Imp. Acad., 2, (5), 214-218.

(1926 b): Geology of the Ikushumbets coal-mining district. 3rd Pan-Pacific Sci. Congr., Guide-Book, Excursion A-2. 1-26, pl. 1.

- (1927): Cretaceous stratigraphy of the Japanese Islands. Sci. Rept. Tohoku Imp. Univ., 2nd Ser., 11, (1), 27-100, pls. 3-9. 
Hakuyu OKADA

Sedimentology of the Cretaceous Mikasa Formation

Piates 19-24 
Plate 19 


\section{Explanation of Plate 19}

Figs. 1, 4, 5, 6 and 7. Examples of the Mikasa sandstone from the western to southwestern wing of the anticline. Note an abundance of chert grains. All are of crossed nicols; $\times 25$.

1. Subgraywacke from the Ikushumbets Valley [II]; KU11.

4. Calcite-cemented subgraywacke from the Pombets Valley [I]; KU85.

5. Ditto ; KU94.

6. Graywacke from the Yamamoto-no-sawa [V]; KU193.

7. Calcite-cemented subgraywacke from the Washi-no-sawa [VII]; KU227.

Fig. 2. Example of the Mikasa sandstone from the eastern wing along the Ikushumbets Valley [XII], Graywacke; KU69. Crossed nicols; $\times 25$.

Fig. 3. Tuffaceous feldspar sandstone of the Upper Yezo Group from the eastern wing along the Ikushumbets Valley; IK1121. Crossed nicols; $\times 25$. 

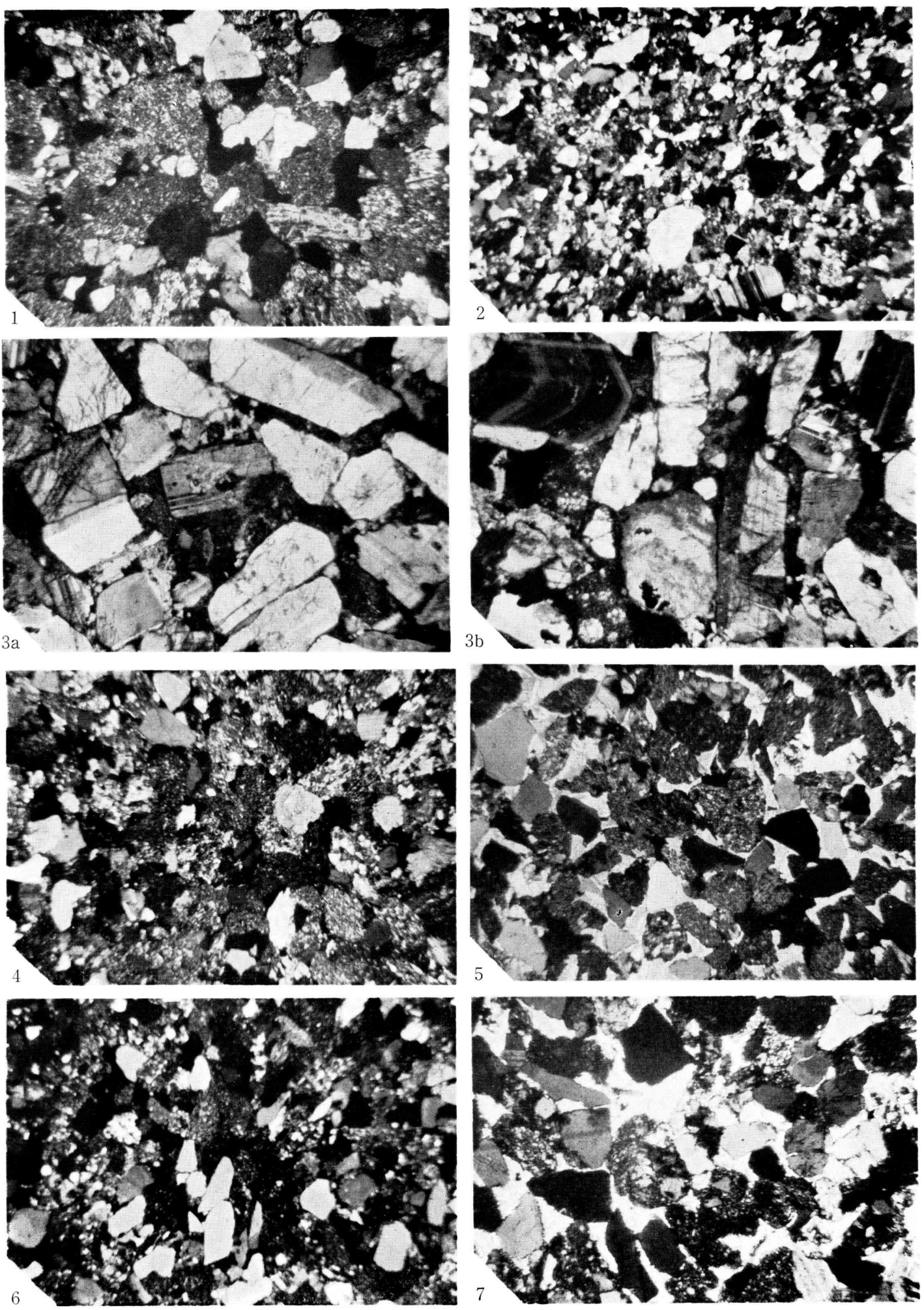

H. OKADA: Sedimentology of the Cretaceous Mikasa Formation 
Plate 20 


\section{Explanation of Plate 20}

Fig. 1. Example of the Mikasa sandstone from the south-western wing of the anticline. Also note an abundance of chert grains. Crossed nicols.

1a. Sparry calcite-cemented subgraywacke from the Nabe-no-sawa [VI]; KU166. $\times 25$. $\mathrm{lb}$ and lc. Details of the same specimen, KU166, showing the abraded chert grains in Figure $1 \mathrm{~b}$ and presence of radiolarian remains in Figure 1c. $\times 50$.

Figs. 2-6. Examples of the Mikasa sandstone from the eastern wing. Crossed nicols; $\times 25$.

2. Calcite-cemented subgraywacke from the Temmaku-no-sawa [IX]; KU177.

3. Graywacke from the Temmaku-no-sawa [IX]; KU178.

4. Calcite-cemented subgraywacke from the Temmaku-no-sawa [IX]; KU185.

5. Graywacke from the Taki-no-sawa [X]; KU242.

6. Calcite-cemented subgraywacke from the Taki-no-sawa [X]; KU249. 

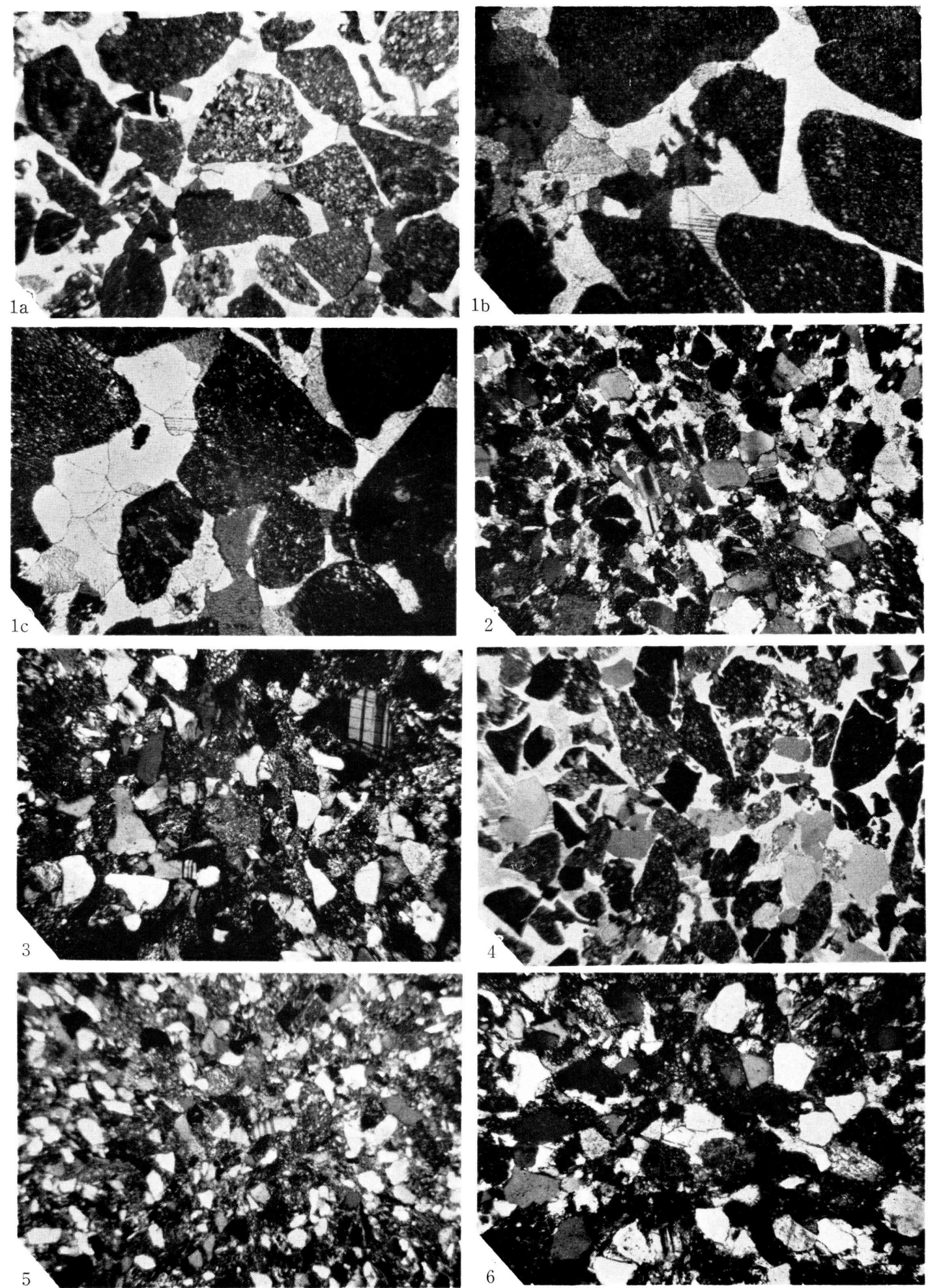

H. OKADA: Sedimentology of the Cretaceous Mikasa Formation 
Plate 21 


\section{Explanation of Plate 21}

Fig. 1. Heavy residue concentrated from a sandstone pebble [KU13p] in the Mikasa sandstone on the western wing of the anticline along the Ikushumbets Valley, showing a preponderance of garnet and zircon. Purple rounded zircon is common. $\times 50$.

Figs. 2-6. Heavy residues of the sandstone of the Lower part of the Middle Yezo Group on the eastern wing of the anticline along the Ikushumbets Valley. Note that all are characterized by garnet and zircon. All figures $\times 50$.

2 and 3. Alternating part (lower part) of the Yunosawa Sandstone. 2: KU17 and $3:$ KU19. 4 and 5. Massive part (main part) of the Yunosawa Sandstone. 4:KU26 and 5:KU29.

6. Sequence above the Yunosawa Sandstone. KU36. 


\section{C.

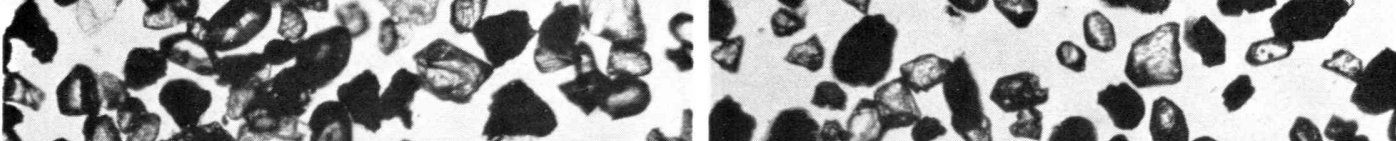

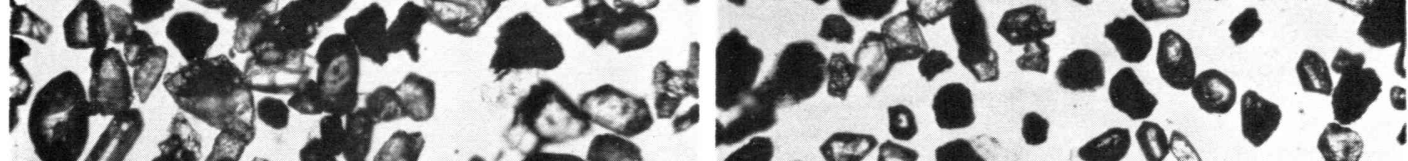

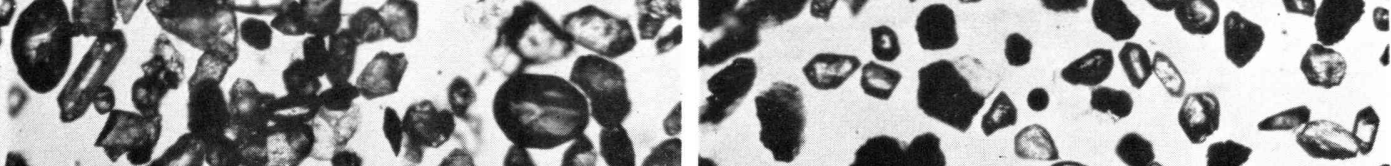

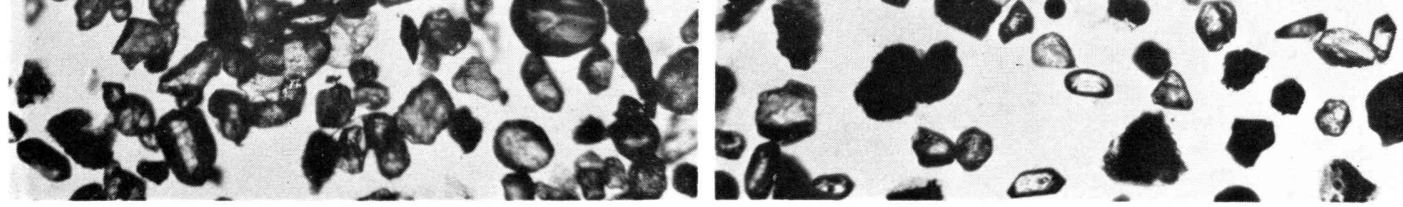

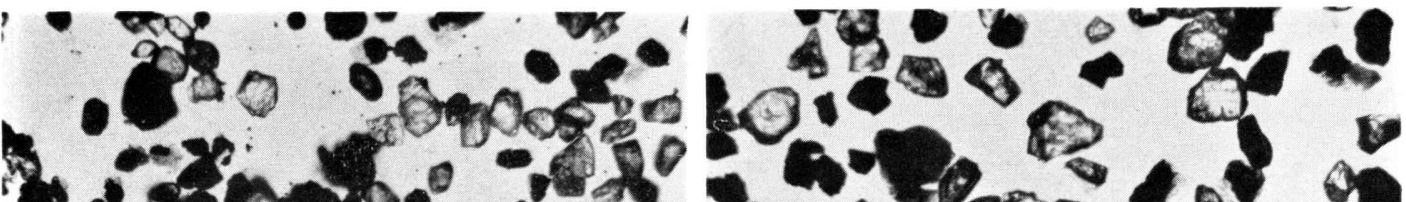

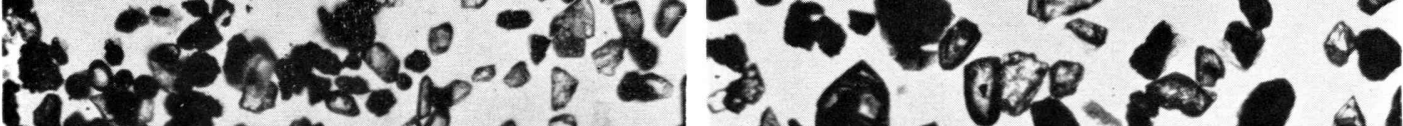

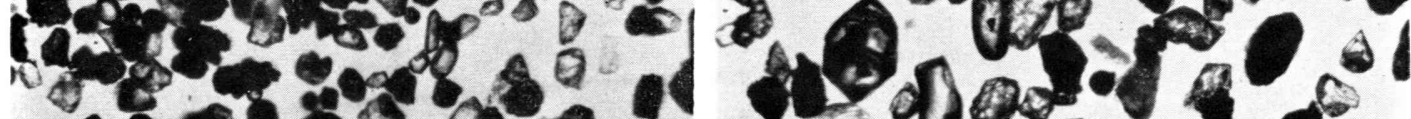

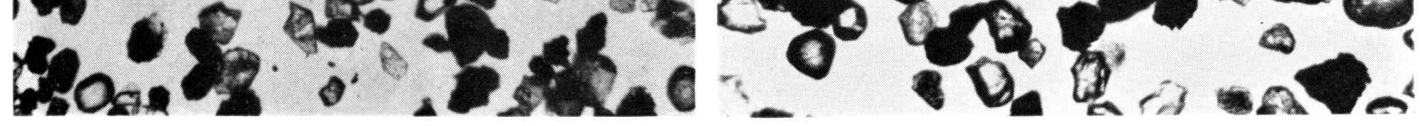

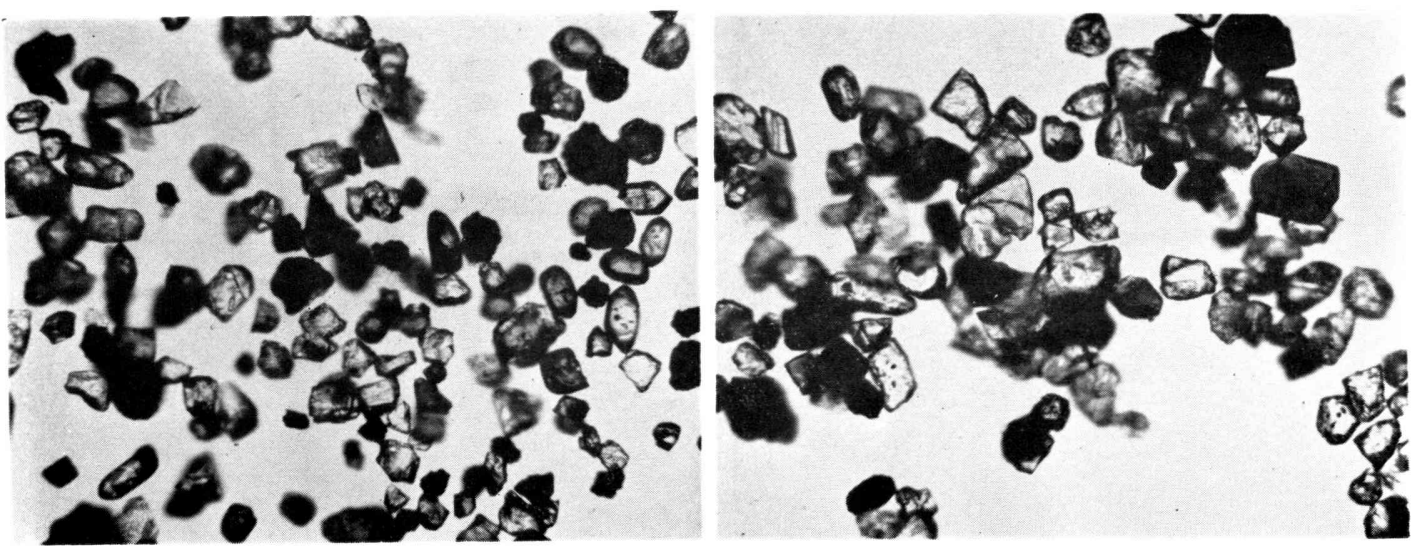


Plate 22 


\section{Explanation of Plate 22}

Figs. 1-4. Heavy residues of the Mikasa sandstone on the eastern wing along the Ikushumbets Valley. Note an abrupt change in mineral association of the Mikasa Formation from that of the underlying strata, lower part of the Middle Yezo Group. All figures $\times 50$.

1. Member IIa of the Mikasa Formation. Epidote and augite are predominated, each of which looks similar on the photo. KU44.

2. Member IIa of the Mikasa Formation. Tuffaceous sandstone characterized by ilmenite (black) and apatite (white). IK1056e.

3 and 4. Member IIb of the Mikasa Formation. Epidote and augite are also abundant. $3:$ KU52 and $4:$ KU53.

Fig. 5. Example of the heavy residue of the Upper Yezo Group on the eastern wing along the Ikushumbets Valley. A marked difference of the Group from the Mikasa Formation is in the preponderance of zircon and garnet. IK976. $\times 50$.

Fig. 6. Mikasa sandstone on the western wing along the Pombets Valley. Epidote is predominant. KU94. $\times 50$. 

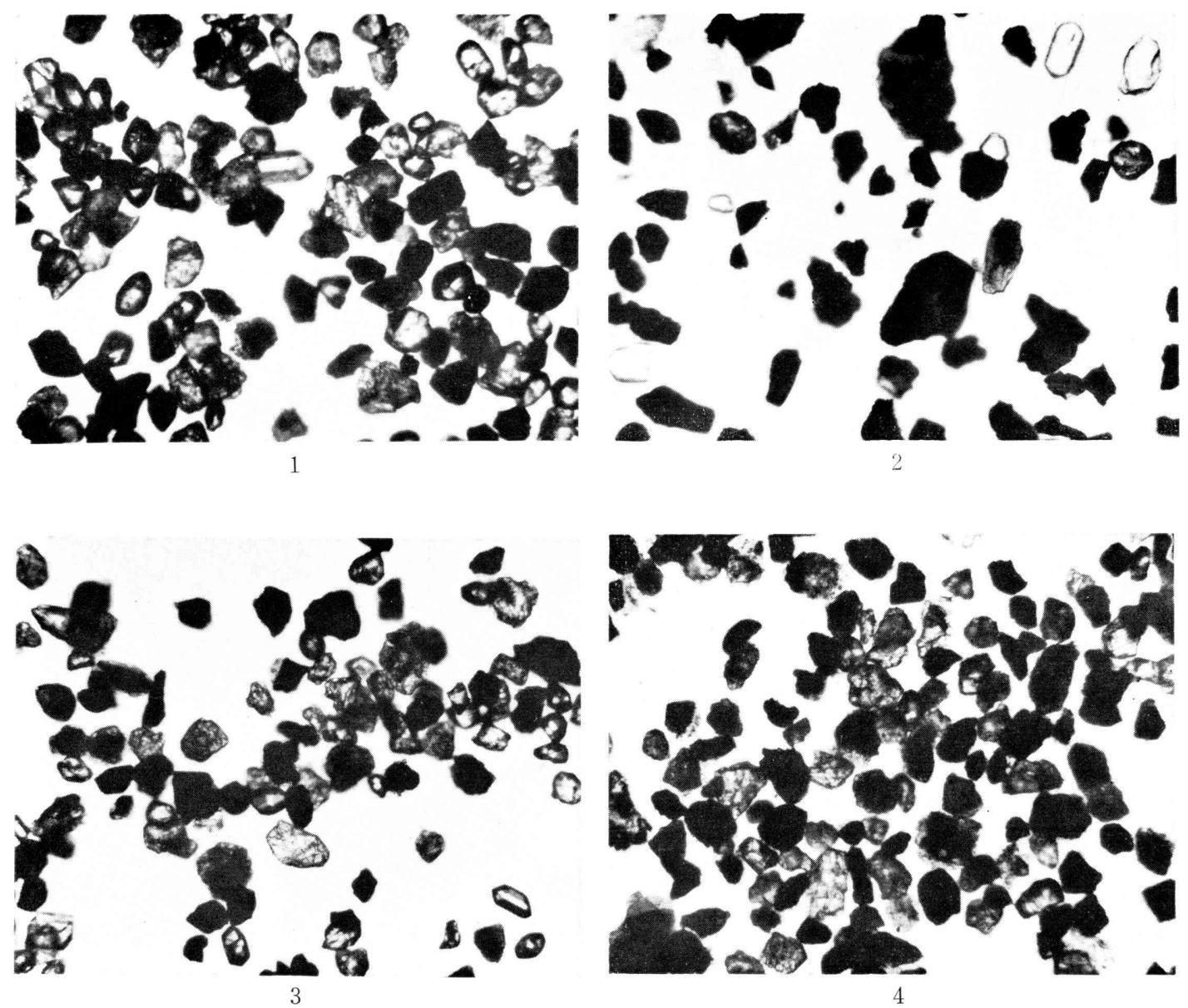

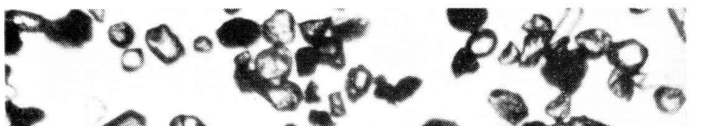

7200000

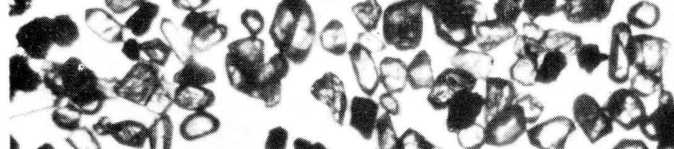
- 08000 on 7. 1000 \% $30090.800 .0 \%$

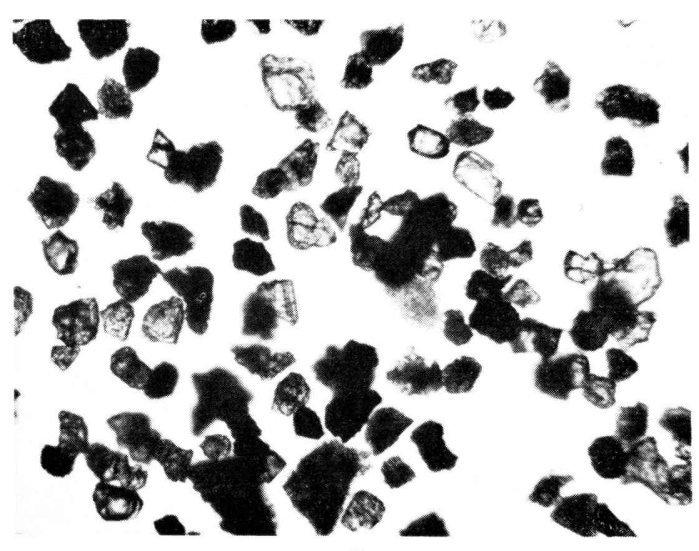

H. OKADA: Sedimentology of the Cretaceous Mikasa Formation 
Plate 23 


\section{Explanation of Plate 23}

Fig. 1. Example of the heavy residue of the sandstones of the Middle Yezo Group exposed on the north side of the Pombets fault. Characterized by zircon, garnet, augite and epidote. KU $142 . \times 50$.

rigs. 2-6. Heavy residues of the Mikasa sandstone on the southwestern to eastern wing of the anticline, indicating the concentration of zircon and garnet. All figures $\times 50$.

2. KU 192, from the Yamamoto-no-sawa [V] (western wing).

3. KU 193, from the ditto.

4. KU 225, from the Washi-no-sawa [VII] (western wing).

5. KU 226, from the ditto.

6. KU 172, from the No. 4 Map-no-sawa [VIII] (eastern wing). 


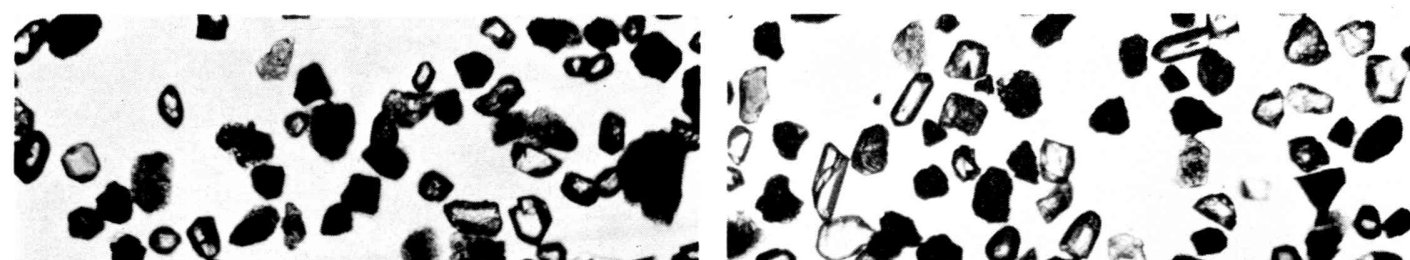

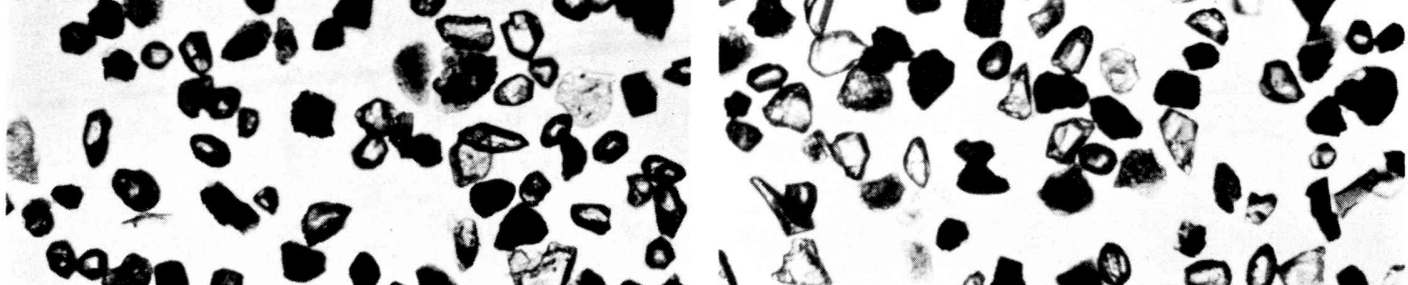

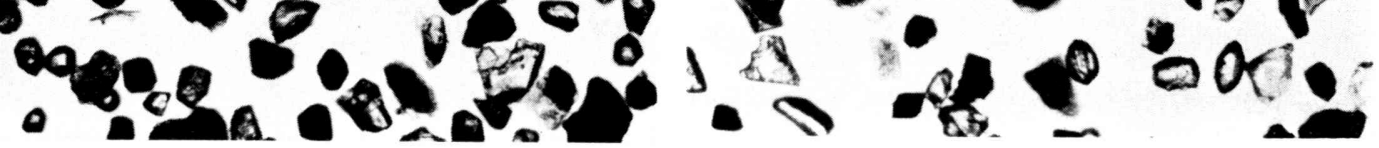

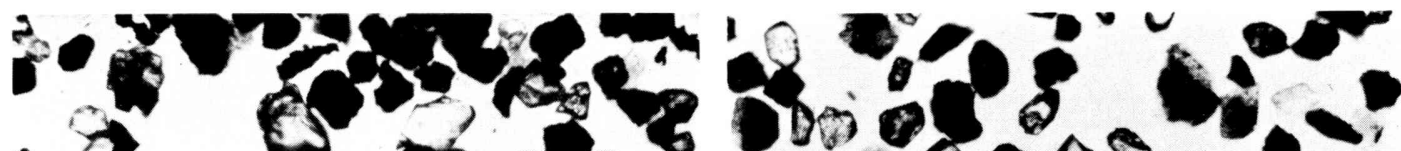

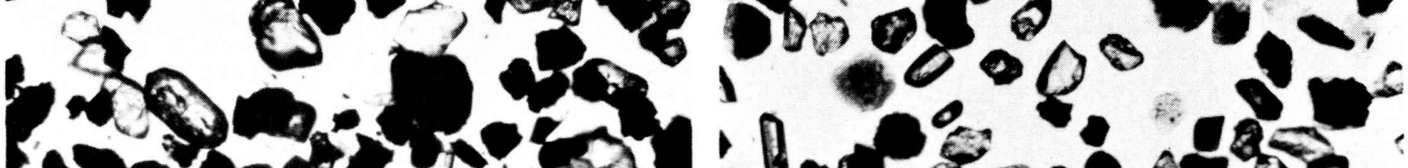

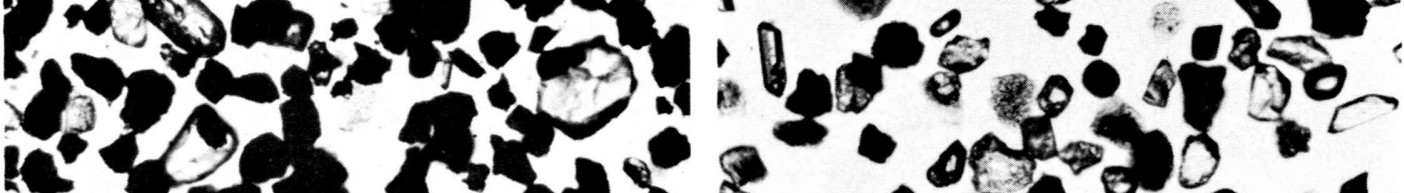

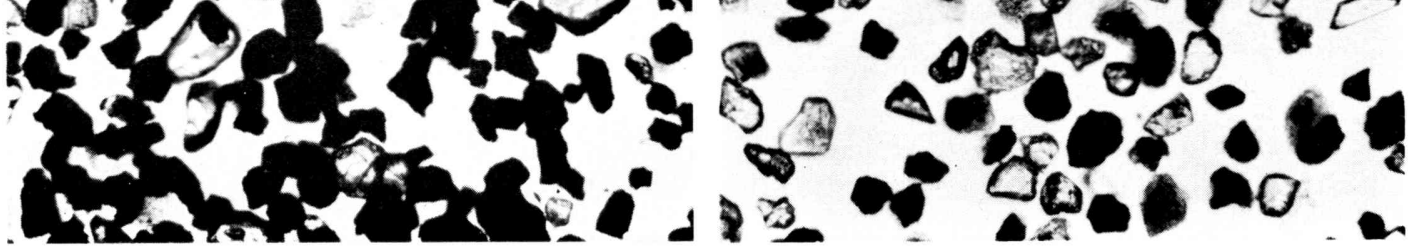

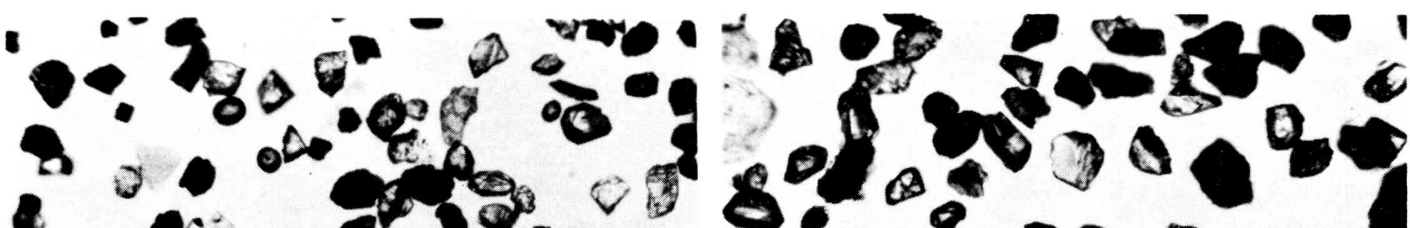

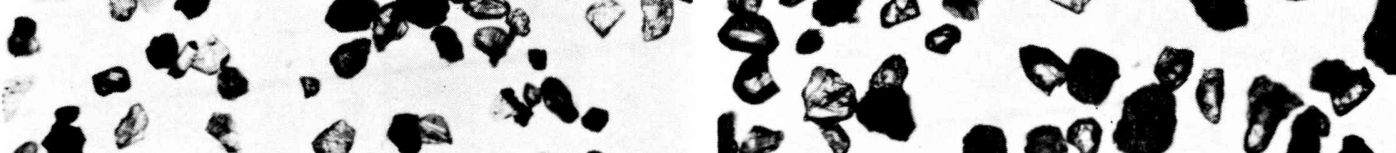

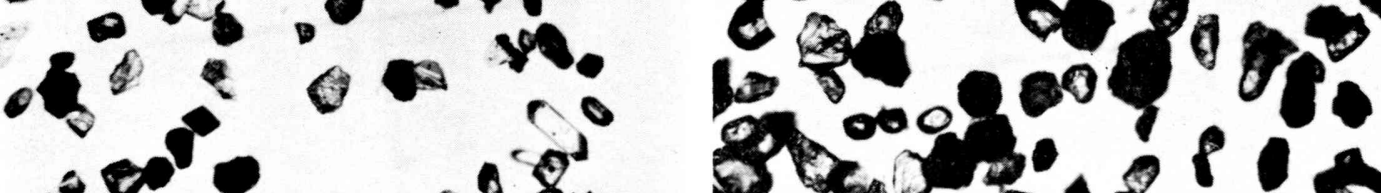

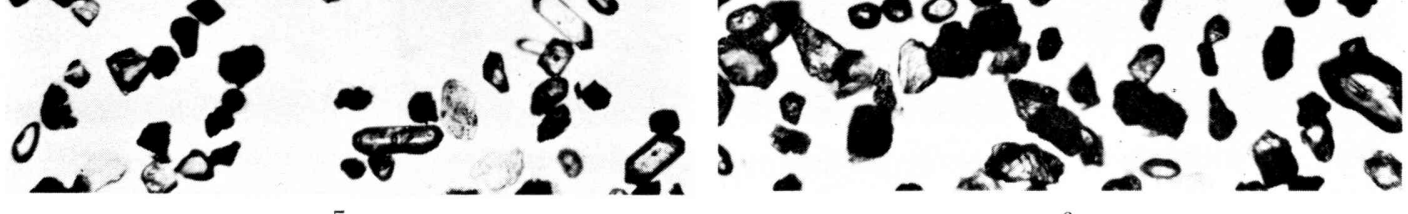


Plate 24 


\section{Explanation of Plate 24}

Figs. 1-2. Heavy residues of the Mikasa Formation in the southern part of the eastern wing, showing the suite of zircon, garnet, epidote and augite. $\times 50$.

1. KU 173 from the No. 4 Map-no-sawa [VIII].

2. KU 183 from the Temmaku-no-sawa [IX].

Figs. 3-6. Heavy residues of the Middle Yezo Group cropped out in the Yubari dome, showing a vertical change in mineral association just as in the type section along the Ikushumbets Valley. All figures $\times 50$.

3. Yb 411 from the Member L1 [K3 $\beta$ ] (Matsumoto and Harada, 1964). Note the preponderance of garnet and zircon.

4. Yb 18 from the Member MK $1[\mathrm{~K} 4 \alpha]$ of the Mikasa Formation (MAtsumoto and HARADA, 1964). Augite is predominant.

5. Yb 253 from the Member MK $3[\mathrm{~K} 4 \beta]$ of the Mikasa Formation (MATsumoto and HARADA, 1964).

6. Yb 21 from the ditto. Note the augite concentrate. 


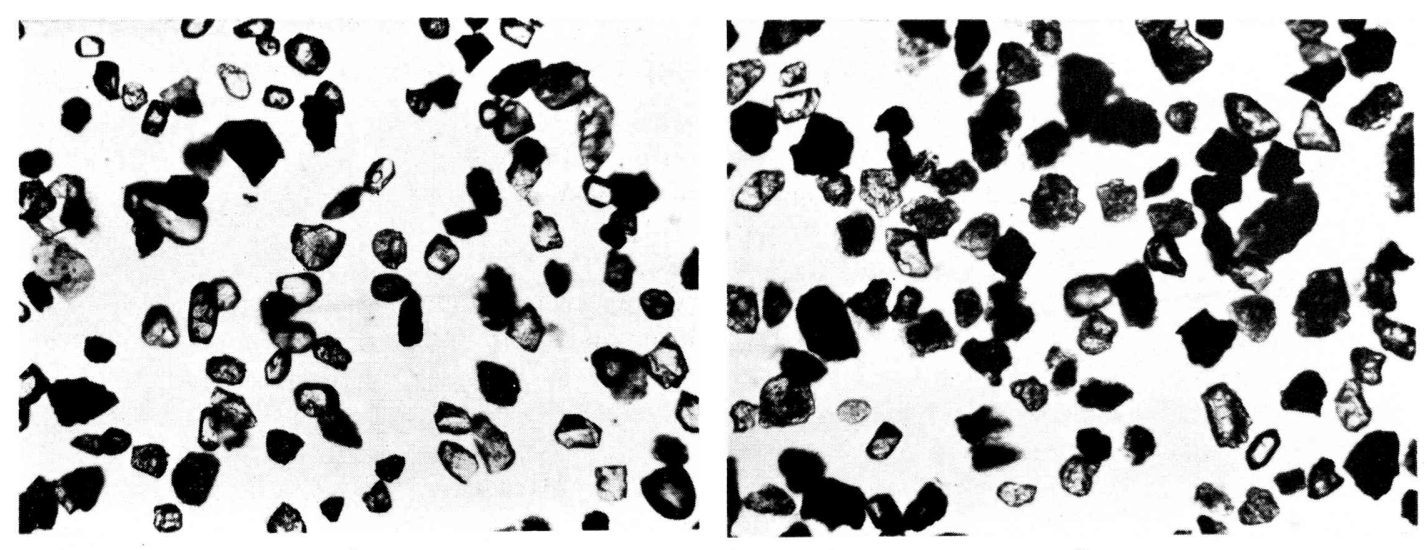

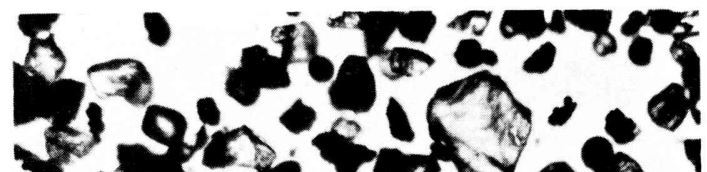

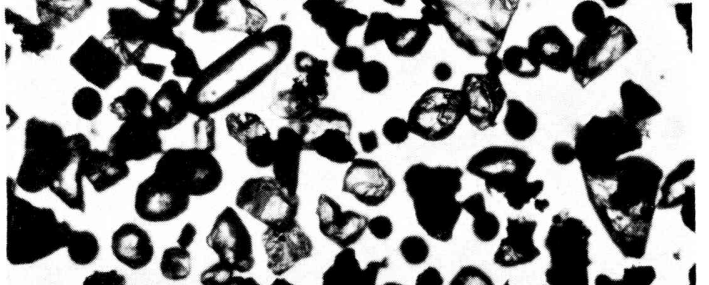

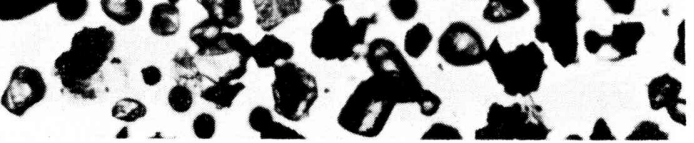

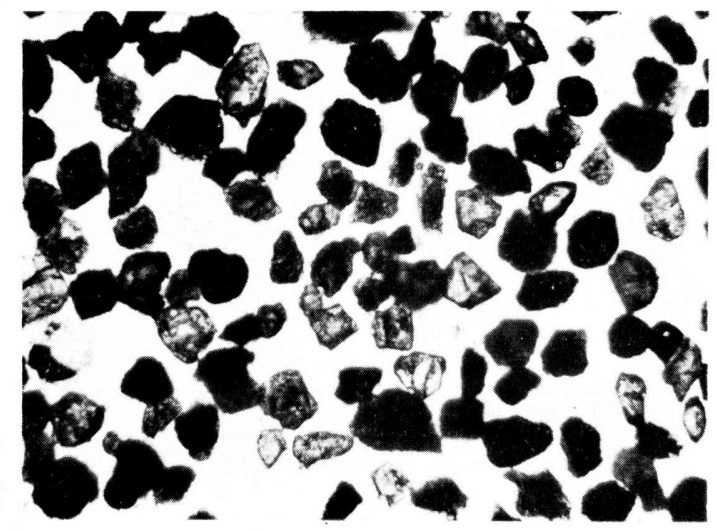

1.3 130 की

\section{$7 \rightarrow 2003$}

110

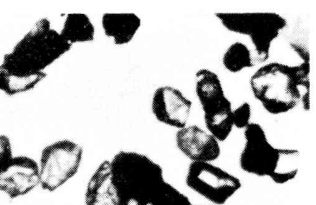

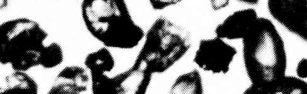
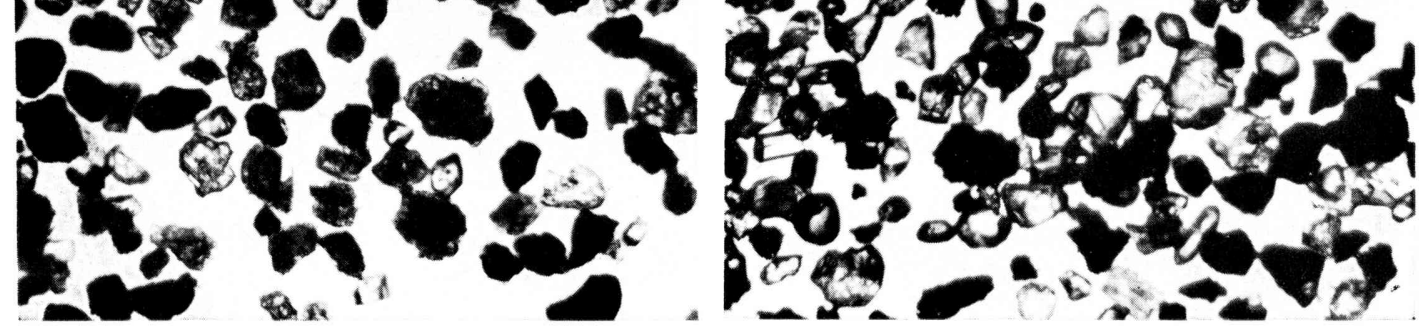

H. OKADA: Sedimentology of the Cretaceous Mikasa Formation 